\title{
Studies on the Biosynthesis of Steroid Hormones
}

\author{
Satoru OTA \\ Department of Obstetrics and Gynecology, Kyoto Prefectural University of Medicine
}

(Director : Prof. Gen-ichi Tokuda, M.D.)

Corticosteroid biosynthesis in the different cellular zones of beef adrenal cortex was studied in vitro.

Various substrates including acetate, cholesterol, pregnenolone, progesterone, desoxycorticosterone, and desoxycortisol were incubated separately with homogenates of fasciculata-reticularis tissue and with slices of glomerulosa tissue.

Although the following sequences were demonstrated in the adrenal cortex, the results of this experiment indicate the absence of $17 \alpha$-hydroxylase in the zona glomerulosa and the absence of 18-hydroxylase in the zona fasciculata and zona reticulalis.

$$
\begin{aligned}
\text { Pregnenolone } & \rightarrow \text { Progesterone } \rightarrow \text { Desoxycorticosterone } \\
\downarrow & \rightarrow \text { Corticosterone } \\
\uparrow & \begin{array}{c}
\text { Aldorone } \\
17-\alpha \text {-hydroxy- }
\end{array} \\
\text { progesterone } & \rightarrow \text { Desoxycortisol } \longrightarrow \text { Cortisol }
\end{aligned}
$$

Incubation of acetate or cholesterol with homogenates or slices of adrenal cortex, however, did not lead to the increase of corticosteroid.

In addition, the incubation of adrenal cortex without substrate resulted in the formation of considerable cortisol and corticosterone, while no cholesterol-route intermediates were detectable in the adrenal homogenates. When the dializate of the adrenal cortex against buffer was lyophilized and incubated with adrenal homogenates, it caused a remarkable increase in the production of corticosteroids. This may be due to the conversion of the dialized precursors to corticosteroids, though these precursors have not yet been isolated.

$17 \alpha$-hydroxylase activities were also demonstrated in the homogenates of HCGtreated-rat testis and in the slices of normal adult human ovaries. These tissues were incubated with $3 \mathrm{H}$-Progesterone and the formation of $17 \alpha$-hydroxyprogesterone- $3 \mathrm{H}$ was clearly demonstrated.

The incubation of full term human placenta with 3 H-Progesterone, however, did not result in the formation of neither $17 \alpha$-hydroxyprogesterone nor phenolic steroids.

From these results, it was suggested that, in human placenta, there is a dominant pathway by which dehydroepiandrosterone is formed from cholesterol, not through progesterone, but possibly by the direct cleavage of the side chain C-17 and C-20; and dehydroepiandrosterone thus produced in turn converts into $\mathbf{4}^{4}$-androstene-3, 17dione and testosterone, and then to estrogens.

(pp. 842 862) 


\title{
Steroid hormone 生合成関する研究
}

\author{
京都府立医科大学産婦人科学教室（主任 徳田源市教授） \\ 太田智
}

(昭和 38 年 5 月 7 日受付)

\begin{tabular}{|c|c|}
\hline 第 1 編 & Corticosteroid 産生に関する問題 \\
\hline 第 1 章 & 緒言 \\
\hline 第 2 章 & Corticosteroid の定性定量法 \\
\hline 第 3 章 & $\begin{array}{l}\text { 牛副腎皮質組織に打けるCortico- } \\
\text { steroid 産生実験 }\end{array}$ \\
\hline 第 4 章 & $\begin{array}{l}\text { 牛副腎皮質組織と各種 Corticoste- } \\
\text { roid intermediate添加培養実験 }\end{array}$ \\
\hline 第 5 章 & $\begin{array}{l}\text { 牛副腎皮質組織中の Corticoste } \\
\text { roid precursor に関する実験 }\end{array}$ \\
\hline
\end{tabular}

\section{次}

第 6 章 総括，考按ならびに結論

第 2 編 Androgen, Estrogen産生に関する問

題

第 1 章 緒言

第 2 章 牛副腎皮質組織と Pregnenolone, Progesterone 添加培養実験

第 3 章 卵策, 皿丸㧄よび胎盤組織と ${ }^{3} \mathrm{H}$ Progesterone 添加培養実験

第 4 章 総括, 考按ならびに結論

\section{第 1 編 Corticosteroid 産生に関する問題}

\section{第 1 章 緒}

言

副需皮質より分泌されるホルモン，すなわち Corticosteroid の研究は，古くから多くの学者によりなされ たが，1937年 Reichstein ら，Kendall が一部の Corticosteroid を結晶の形で取り出すてとに成功して以 来，急速に進歩し，つい1952年に Simpson, $\left.{ }^{2}\right)$ Tait $^{3)}$ らにより，また，Neher，Wettstein，Reichstein ${ }^{4}$ らによ り強力な mineral corticoid である Aldosterone が発見されるに至つた。 そして現在までのとてろ副腎皮 質より抽出されたステロイドは40種以上にのぼり，そのうち副腎皮質より分泌される活性 Corticosteroid は Cortisol, Corticosterone, 17-hydroxy-11-desoxycorticosterone, Cortisone, 11-desoxy-corticosterone, Aldosterone の6 種であるとされている。一方，副腎皮質における Corticosteroid の生合成経路に関しては Hechter ${ }^{5}$ フ らにより詳細な研究がなされ，一見完成されたが見えた。かれらによると Cholesterol が重 要な intermediate (中間代謝物) であるとみているが, Cholesterol がてれらの生合成の intermediate と して必ずしも必要でないとの報告もあり，また Heard らは $\mathrm{CH}_{3}{ }^{14} \mathrm{C}-\mathrm{OONa}$ を静脈投与した妊馬尿中には ${ }^{14} \mathrm{C}$-estrogen を分離しえたが8)，Cholesterol-4- ${ }^{14} \mathrm{C}$ 投与例では，尿中に ${ }^{14} \mathrm{C}$ 検出しなかつたと述へており， また ${ }^{14} \mathrm{C}$-acetate による培養実験 ${ }^{6)}$ で， ${ }^{14} \mathrm{C}$-Cortisol, ${ }^{14} \mathrm{C}$-Corticosterone のような Corticosteroidをえたが， ${ }^{14} \mathrm{C}$-cholesterol には転化しないという結果をえて Cholesterol を経ない Corticosteroid 生成経路の存在す る可能性をも考えられている. 徳田ら ${ }^{10)} も$ 最近ての non-cholesterol の問題に関する詳細な綜説を発表した. また，副腎皮質の形態学的，組織学的構造の 細胞層と分泌されるホルモンとの関係については，今日まで escalater theory や皮質 2 元論 ${ }^{11}$ が提唱されたが，いずれも確定的でなく現在に至つている.

てのように，副腎皮質において行なわれる Corticosteroid の産生経路およびその構造と機能との相関につ いては，なお不明の点が多く，てれらを解明するために，今回次のような培養実験をててろみ，てれらの問 題について検討を加えた。 


\section{第 2 章 Corticosteroid の抽出, 分離, 定性および定量法}

incubation mixture よりの Corticosteroid の抽出には, chloroform を用い, methanol と petroleum ether の分配により脂肪，色素などを除去し， column， paper-chromatography を系統的に用い，各々の Corticosteroid を分離, 出来るだけ特異的な反応を組合わすととにより定性定量した.

なお比色計は，Bausch \& Lomb社製および日立製作所製日立 EPU-24型分光光電光度計を用いた.

\section{第 1 節 抽出}

incubation mixture を Fig. 1 の方法で抽出を行なつた。すなわち， suspending media を遠心沈澱し 上清と沈渣を分離, 沈渣をさらに水で 2 回抽出し, 先の上清と合わせ chloroform で抽出した. 水洗後, chloroform を減圧蒸溜し，60\% methanol-petroleum ether で分配し，脂肪を除去し，methanol を蒸発 せしめたのち，その水層を chloroform で再び抽出し，てれを減圧蒸発乾固し粗抽出物を得た。

Fig. 1. Extraction of incubation mixture

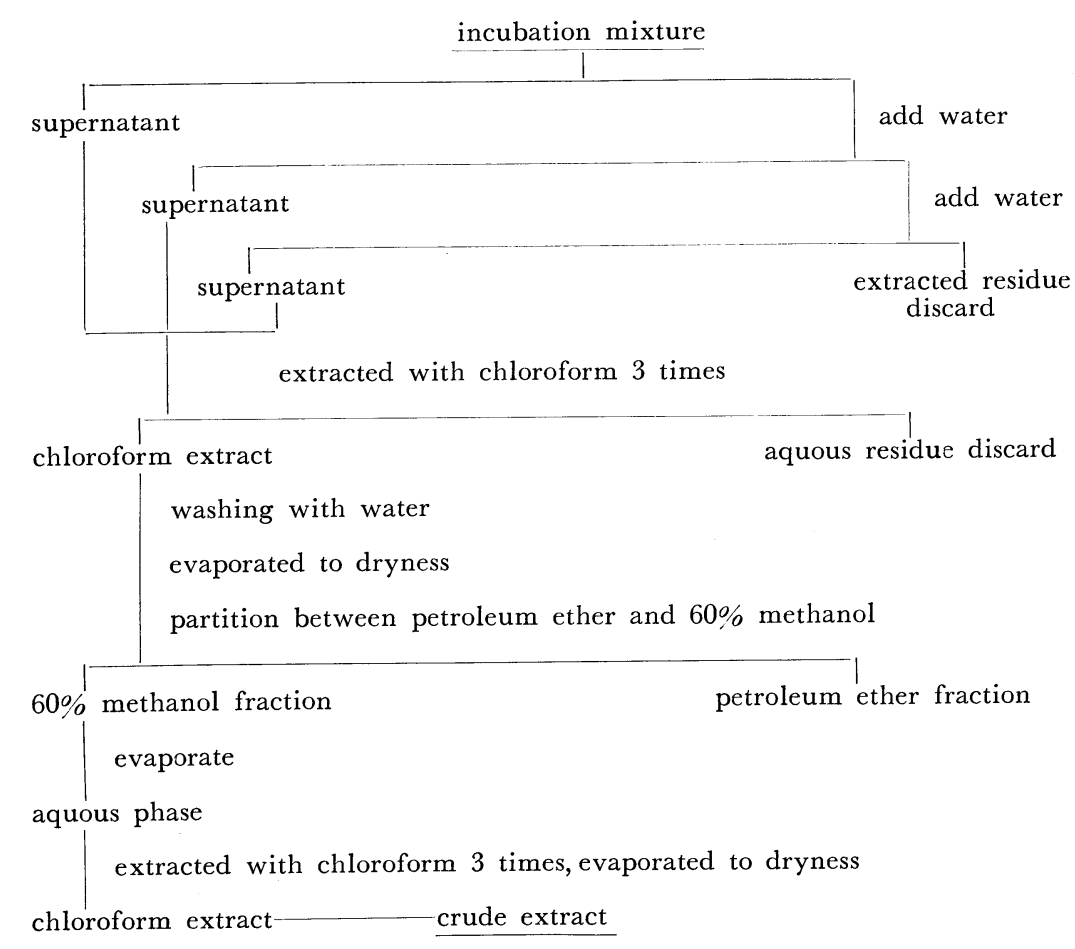

\section{第 2 節 Steroid の分離法}

粗抽出物よりの Steroid の分離は column chromatography および paper chromatography を系統的 そ組合わせ用いた。

\section{第 1 項 Column chromatography}

精製活性化した florisil (5gm) を用い, chloroform にて直径 $1 \mathrm{~cm}$, 高さ $7 \mathrm{~cm} の$ florisil column を作 り, 上述の減圧蒸溜粗抽出物を $5 \mathrm{cc}$ chloroform に溶解し，乙れに注入し吸着せしめる．次に chloroform $5 \mathrm{cc}, 1 \%$ methanol chloroform 25cc, 次いで 25\% methanol chloroform 50cc で連続溶出し, 25\% methanol chloroform 分画を集め，減圧蒸溜し，次の paper chromatography に使用する。また，直ちに 
定性定量反応を行ない Corticosteroid 量を測定する，なお，第4 章の実験にはこの column chromatography を省略した。

第 2 項 Paper chromatography

溶媒系としては Bush法 ${ }^{12}$ の benzene-methanol-water (1000:500:500) system ( $\mathbf{B}_{5}$ system), ligroinemethanol-water (1000:800:200) system (Ba system), ligroine-benzene-methanol-water (667:333 :

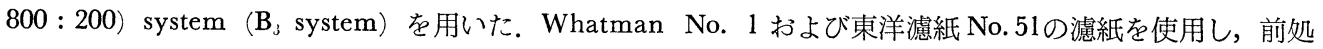
置せずに下首を固定相, 上首を移動相として， $25^{\circ} \mathrm{C} て ゙ 2 \sim 3$ 時間展開し，乙れを風乾し，各 band を切りと り methanol および chloroform で溶出蒸発乾固し, 次の Steroid の定性定量反応に供した.

\section{第3 節 Steroid の定性定量法}

次の各種定性定量反応を組合わすととにより各 Corticosteroid 量を測定した。

\section{第 1 項 Paper Chromatography 上Rf值の比較}

Paper chromatography 上同時に展開した標準 Steroid と, そのRf值を比較する.

第 2 項 紫外線吸収写真および吸収スペクトル

$\Delta^{4}$-3-Ketosteroid の確認に用いる。

第 3 項 硫酸 Chromogen spectrum ${ }^{13)}$

吸収 spectrum は各 Steroid により特有であり, 標準 Steroid と比較する.

第 4 項 沃度カリ溶液による呈色反応 ${ }^{14}$

Paper chromatography 上， $\Delta^{4}$-3-Ketosteroid の存在を呈色反応䎲より確認する.

第 5 項 Porter-Silber chromogen 反応 ${ }^{15}$

Phenylhydrazine hydrochloride が，17，21-dihydroxy-20-Keto steroid 亿特異的に反応し呈色する.

第 6 項 Blue tetrazolium 反応 ${ }^{16}$

20,21 $\alpha$-Ketol side chain に対する反応で，アルカリ溶液中で Blue tetrazolium が還元されて紅紫色を 呈す.

第 7 項 INAH 反応 ${ }^{17}$ :8)

$\Delta^{4}$-3-Ketosteroid が isonicotinic acid hydrazide と反応し淡黄色を呈す.

第 8 項 Zimmermann 反応 ${ }^{19}$

$\mathrm{C}^{17}$ の-CO基がアルカリ溶液中で m-dinitrobenzene と反応して呈色する反応で，17-Ketosteroid の定 性定量に用いる.

\section{第 3 章 牛副堅皮質組織における Corticosteroid 産生実験}

副腎皮質組織中に存在する Corticosteroid precursor から Corticosteroid が産生されるととは Vestling および Lata ${ }^{20)}$ により発表された。これら endogenous precursor より Corticosteroid が 産生されるため には，組織中の酵素の存在とともに各種の cofactor を必要とし，てれらに関する報告は数多くあるが， Corticosteroid 産生に及ぼすてれら cofactor の濃度および時間的変化などを検討しようとして次のような 実験を行なつた。

\section{第 1 節 実験方法}

牛副腎を屠畜場で採取後, 直ちにドライアイスと共に魔法瓶に詰めて冷却しながら実験室に運び実験に供 した. 牛副腎の capsule stripping を行なつて, 束, 網状層組織を同量の $0.25 \mathrm{M}$ sucrose phosphate buffer solution（pH 7.0) または Krebs-Ringer phosphate buffer solution (pH 7.4) で homogenize したのち $800 \times \mathrm{g}$ で 5 分間遠心沈澱し，その上清に sodium fumarate $(0.005 \mathrm{M})$, nicotin amide $(0.005 \mathrm{M})$ を加え た. また sucrose phosphate buffer solution を用いた際は $\mathrm{Mg} \mathrm{SO}_{4}(0.005 \mathrm{M})$ を添加調製した.

次いで $37^{\circ} \mathrm{C}$ で基質を加えないで培養し，前章の方法にて Gorticosteroid を抽出し，florisil による column chromatography を行ない, $25 \%$ methanol chloroform 分画を Blue tetrazolium反応，INAH 反応およ 
び Porter-Silber chromogen 反応にて定量した。標準としては Cortisol を用いた.

また一方, paper chromatography により Corticosteroid を分離確認した.

\section{第 2 節 実験成績}

\section{第 1 項 ATP，DPNH およびその両者の影響}

上記皮質束網状層組織の homogenate $2 \mathrm{cc}$ を $37^{\circ} \mathrm{C} て ゙ 30$ 分間空気流通下で振とう培養した。 まず ATP (adenosin triphosphate) 単独の濃度変化に対する Corticosteroid 産生におよぼす影響をみると，ATP の 効果は Fig. 2 のように1.5mM迄漸増する結果をえた。またDPNH (reduced diphosphopyridine nucleotide) 単独添加の場合の効果は $0.5 \mathrm{mM}$ 迄急速に上昇するが，以後漸増する。また $0.25 \mathrm{mM}$ 濃度の ATP 存在 下における DPNH の濃度変化をみると, DPNH 単独添加の場合とほぼ平行関係を示した。

\section{第 2 項 培養時間の影響}

$5 \mathrm{mM}$ sodium fumarate, $5 \mathrm{mM}$ nicotin amide, $1 \mathrm{mM}$ ATP, $0.25 \mathrm{mM}$ DPNH の各 cofactor t含有せる

Fig. 2. Effect of ATP, DPNH and their combination on biosynthesis of corticosteroid

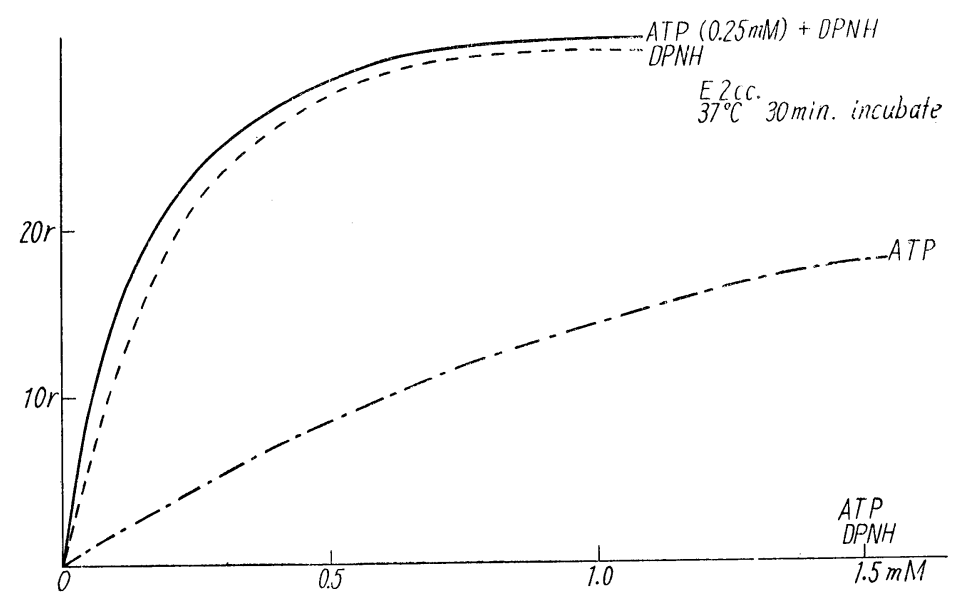

Fig. 3. Effect of incubation period on biosynthesis of corticosteroid

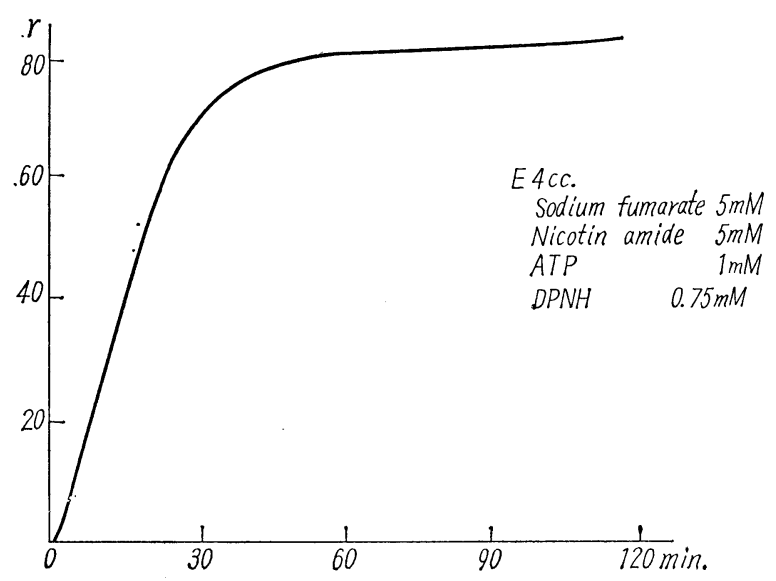


上記皮質束網状層組織の homogenate $4 \mathrm{cc}$ を $37^{\circ} \mathrm{C}$ で空気を通じて振とう培養した，基質を添加せずに Corticorteroid 産生量に対する培養の時間的変化を みると Fig. 3 に示すようで，45分前後でほぼ最高 值に達するととが認められた。一方とのような生成 steroid を florisil による column chromatography および paper Chromatography で分離したととろ Fig. 4 のように，主として Corticosterone および Cortisol であるととをみた。

以上の実験で基質を加えない場合でも，副腎皮質 中に Corticosterone または Cortisol になる何らか の Corticosteroid precursor が存在し, 副腎組織中 の酵素の存在下に ATP, DPNH などの各 cofactor の添加で，比較的短時間の培養で Corticosteroid C の産生が証明された。

\section{第 4 章 牛副腎皮質組織ट各種 Cortico-} steroid intermediate 添加培

\section{養実験}

副婜皮質におけるCorticosteroid の生合成に関し ては Hechter, Heard, Reichstein らの実験があり, いずれも最終産物は Cortisol, Corticosterone, Aldosteroneであるてとが認められている，一方 Swann ${ }^{2 !)}$ は動物の脳下垂体摘出により，副腎皮質における組 織上の変化は，束網状層の萎縮であり，球状層にお いてはほとんど変化のないととをみている，O’Donnell ${ }^{22)}$ らは ACTH (Adrenocorticotrophic hormone）の注射により，尿中 17-hydroxy corticoid の増加をみると同時に，束網状層は急速に反応し幅が広 くなるが，球状層には変化が認められなかつたと報告している。また slice の培養実験では Ayres は球状 層組織の培養実験で Aldosterone の産生が認められたのに反し，束網状層組織の同実験では認められなか つたと報告している。このように副腎皮質における Corticosteroid 産生は各㬝により Corticosteroid の種 類が異なり，Hechter $\left.{ }^{23}\right)$ が想像したような Corticosteroid 産生の各経路が，各凮で各々独立に行なわれてい るのであるか，あるいは副腎中の血流にそつて，すなわち外層で DOG (11-desoxycorticosterone), Sub S (17-hydroxy 11-desoxycorticosterone) などが，さらに内層に進んで，束状首ないし網状首組織で Cortisol, Corticosterene が産生されるもの 24 であるかについては，現在なお解明されていない問題である.

そこで，本実験では牛副腎の capsule stripping を行なつて，球状層組織と束網状層組織とに出来るだけ 分離し，それぞれに対して基質 (Corticosteroid intermediate) を添加培養し，産生される Corticosteroid を分離，定性定量するととにより検討を加えた。

\section{第 1 節 実験方法}

牛副腎の capsule stripping を行なつて，皮質組織を球状層と束網状層とに分け，前者は slice に，後者 は homogenate にして培養実験に供した。 incubation medium には cofactor として 5mM sodium fumarate, $5 \mathrm{mM}$ nicotin amide, $1 \mathrm{mMATP}, 0.5 \mathrm{mM}$ DPNH を含有する Krebs-Ringer phosphate buffer

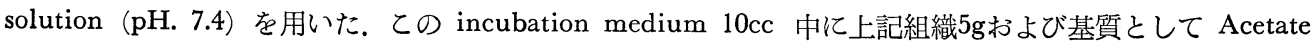


または Corticosteroid inteamediate とみなされる steroid を0.2ccの propylen glycol に溶解し, $200 \mathrm{cc}$ の培養容器に入れ, $37^{\circ} \mathrm{C} て ゙ 2$ 時間, 空気流通下に振とう培養した，対照 としては同条件にて基質を添加せず 培養した，各々の Corticosteroidの 抽出, 分離, 定量は第 2 章で述べた 方法により行なつた。

\section{第 2 節 実験成績}

第 1 項 Acetate 添加培養実験 牛副腎皮質の球状層，束網状凰組 織5gをそれぞれ slice および homogenate し，各々を前述の cofactor を含有した incubation media 10cc 中で Acetate $20 \mathrm{mg}$. を添加培養しだ 対照としては Acetate を添加せず培養抽出し, ligroine-methanolwater system および benzene-methanol-water system で paper chromatography を行ない Fig. 6 のよ うな結果を得た. 球状層, 束網状首共, 基質なしに行なつた培養成績と比較し, 明らかな変化を認めない. なお普通文字で書いてあるのは paper chromatography 上明らかなスポットを認めなかつたもの，ゴチッ ク字は明らかにスポットを拝めた印である。最初の（）内の数値は，基質を添加するととなく培養したと

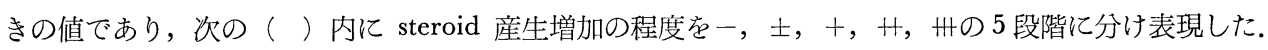

\section{第 2 項 Cholesterol ${ }^{-}$添加培養実験}

前項と同じ方法にて Cholesterol 20mg. を添加培養した実験結果は Fig. 7 亿示すようである. 球状首， 束網状層共測定結果は軽度の産生増加を認めたが，Cortisol の産生増加は著明ではなかつた。また Corticosterone も同じように明らかな産生増加をみなかつた。 この incubation medium では Cholesterol より Corticosteroid への転換は, はつきり確認しえなかつた.

\section{第 3 項 Pregnenolone 添加培養実験}

球状層，束網状層に Pregnenolone 1mg. を添加培養した結果は Fig. 8 に示すようで，束網状層では Corticosterone, Cortisol とも対照に比較し明らかに増量している. 球状層では Corticosterone の明らかな

Fig. 6. Biosynthesis of corticosteroid from acetate

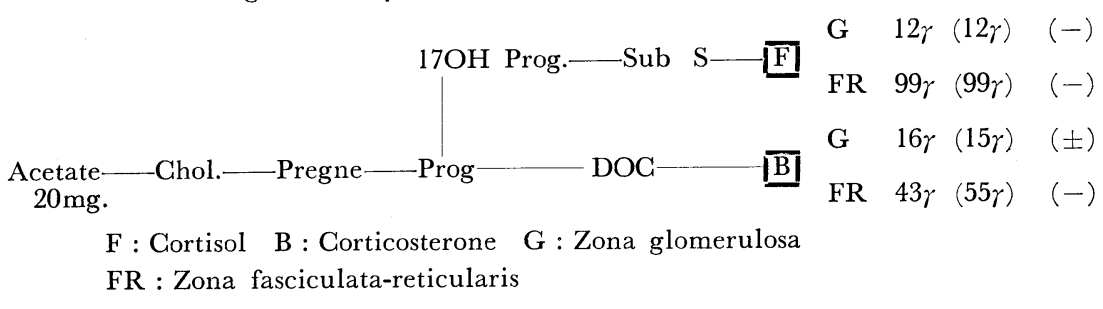

Fig. 7. Biosynthesis of corticosteroid from cholesterol

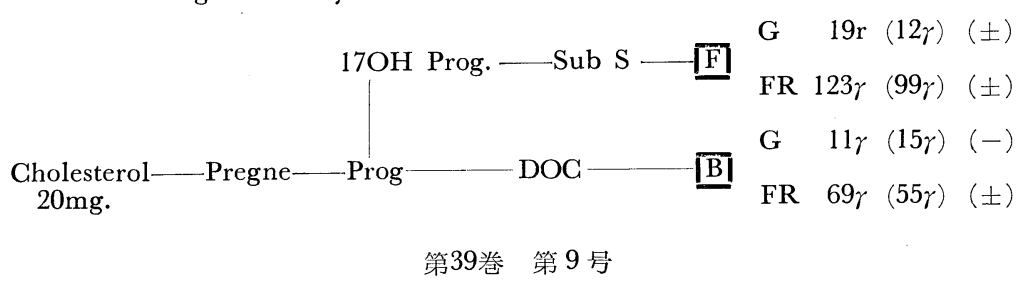


Fig. 8. Biosynthesis of corticosteroid from pregnenolone

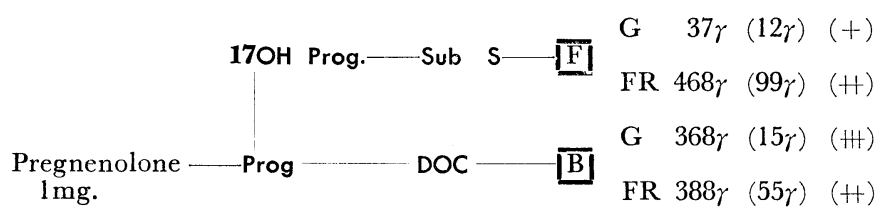

産生増加を認めるのに反し, Cortisol の産生増加は著明ではなかつた．また ligroine-methanol-water system で展開したものでは，球状層の方では Progesterone および DOCのスポットが浔められた，以上より，束 網状層では Pregnenolone より Progesterone, DOG という経路を経て, Corticosterone が産生される可能 性を十分認めた。一方 Cortisol も著明に産生される。球状層では Pregnenolone より Progesterone, DOG を経て Corticosterone の産生が明らかにみられるに反し，Cortisol の産生は，それはどはつきりしたもの は認められなかつた。 ある程度 Cortisol のスポットが現われたが，てれは capsule stripping にする際に， 束網状層の細胞が球状層に混入したために Cortisol が産生されたものであるかもわからない.

\section{第 4 項 Progesterone 添加培養実験}

Progesterone $1 \mathrm{mg}$. を添加培養すると，束網状層においては Corticosterone, Cortisol いずれも著明な産 生增加をみた。一方球状層では Corticosterone のスポットが大量認められるに反し，Cortisol のスポット は非常に少なく，ての層では Pregnenolone 添加培養実験と同じように Progesterone から Cortisol への代謝経路は認めら れなかつた. したがつて Prog. $\rightarrow$ DOG $\rightarrow$ Corticosterone の代謝経路が, 球状, 束網 状の双方すなおち全風において認められる が, Prog $\rightarrow$ Sub S. $\rightarrow$ Cortisol の代謝経路は 束網状層では認められるが, 球状層では認 められなかつた。

\section{第 5 項 DOC (11-desoxy corticosterone)}

\section{添加培養実験}

DOG $1 \mathrm{mg}$. の添加培養実験では Corticosterone は球状層でも束網状層でも著明に 産生されるが, Cortisol のスポットは認め られず DOG $\rightarrow$ Cortisol の代謝経路の存在 は認められなかつた。

球状層に DOG を添加培養する際 ATP の濃度が低い場合に $\Delta^{4}$-Androstenedione と Progesterone の間に $\Delta^{4}$-3-Ketosteroid のスポットを認めた。

ATP の濃度を高くすると，てのスポッ トは消失した。この $\Delta^{4}$-3-Ketosteroid は DOG $\rightarrow$ Corticosteroneへの代謝経路の中間 産物かDOG $\rightarrow$ Aldosterone, Corticosterone への代謝産物であるかは不明である。また 束網状層では，てのようなスポットは現わ れなかつた。

Fig. 9. Biosynthesis of corticosteroid from progesterone

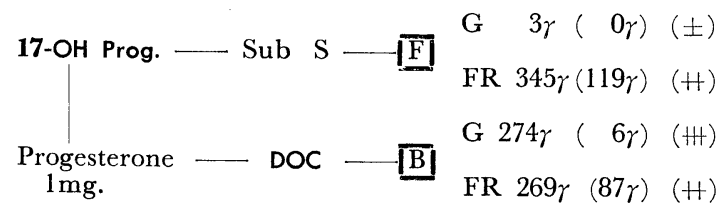

Fig. 10. Biosynthesis of corticosteroid from 11-desoxycorticosterone

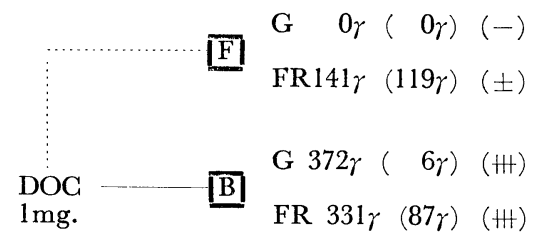

Fig. 11. Biosynthesis of corticosteroid from $17 \alpha$-hydroxy progesterone

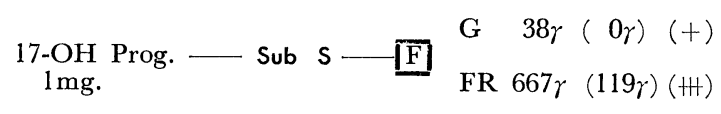

Fig. 12. Biosynthesis of corticosteroid from 17-hydroxy-11-desoxy corticosterone

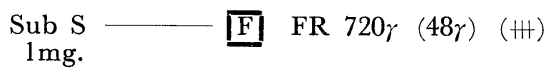




\section{第 6 項 $17 \alpha$-hydroxy progesterone 添加培養実験}

17 $\alpha$-hydroxy-progesterone を添加せる場合は束網状層で Cortisol が著明に増加しているにかかわらず， Gorticosterone の増加は見られず，また球状層では Cortisol がやや増加しているように見えるが，てれは 束網状層の contaminate が起てつたためであると考えられる.

\section{第 7 項 Sub S. (17-hydroxy-11-desoxy corticosterone) 添加培養実験}

$17 \alpha$-hydroxy progesterone を添加培養した場合と同様 Sub. S. を添加培養した際には, 束網状層のみで Cortisol への転換を認めた。

\section{第 5 章 牛副腎皮質組織中の Corticosteroid precursor に関する実験}

Corticosteroid の生合成については Cholesterol が重要な intermediate（中間代謝産物）とみなされてい るがままた Cholesterol を経ない経路の存在する可能性も Hechter ら ${ }^{25)}$, Heard ${ }^{699}$ らにより古くから間接 的に考えられており，現在なお明らかでない，そてで副腎皮質中に存在する Steroid precursor を検索する ととにより, non-cholesterol route の intermediate をえようと考え，次のような培養実験を試み検討した。

\section{第 1 節 実験方法}

牛副腎皮質中に存在する corticosteroid intermediate の抽出は Fig. 13 のようである.まず牛副腎皮質

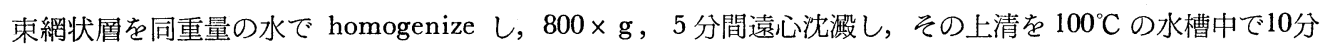
間加熱濾過する。 また $5{ }^{\circ} \mathrm{C} て ゙ 24$ 時間セロファン膜（No.350）で透析したもの，それぞれを Krebs-Ringer phosphate buffer solution (pH. 7.4,)，または 0.25M sucrose phosphate buffer solution (pH. 7.0) に補 正し，それぞれ boild P (BP) および dialized P (DP) と名ずけた。 また，セロファン膜で透析したもの を，さらに lyophilize したものを lyophilized P (LP), また boild P から chloroform 可溶性物質を抽 出した残りの chloroform 不溶性のものを chloroform unsoluble boild P (GUBP) と名ずけた. 一方 Corticosteroid 生合成の反応系としては第 3 章で得た酵素系，すなわち，牛副腎束網状層組織を KrebsRinger phosphate buffer solution または $0.25 \mathrm{M}$ sucrose phosphate buffer solution で homogenize した のち500× g， 5 分間遠心沈澱し，その上清（Eと名ずける）を用い, sodium fumarate (5mM), nicotinamide $(5 \mathrm{mM}), \mathrm{MgSO}_{4}(5 \mathrm{mM}), \mathrm{ATP}(1 \mathrm{mM})$, DPNH $(0.5 \mathrm{mM})$ の各 Cofactor を加えた. そして, 先に 述べた" $\mathrm{P}$ "物質と共に $37^{\circ} \mathrm{C} て ゙ 30$ 分間空気流通下に振とう培養した.

Fig. 13. Intermediate of corticosteroids

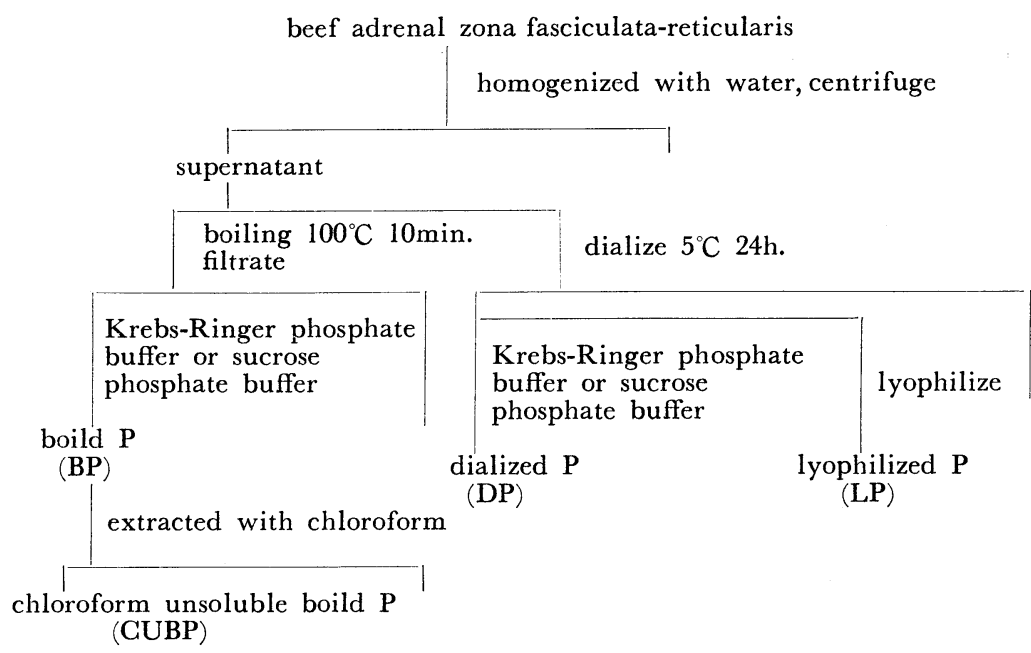




\section{第 2 節 実験成績}

\section{第 1 項 Boild P 添加培養実験}

上記 $\mathrm{E} 5 \mathrm{cc}$ に boild P10cc を

加え sodium fumarate, nicotin amide, ATP, DPNH 等の存在下 に培養抽出した。 Corticosteroid の分離，定量には florisil による column chromatography を行な い, 25\% methanol chloroform fraction を減圧蒸発乾固し, Porter-Silber chromogen 反応, Bluetetrazulium 反応，INAH 反応 を行なつた. Fig. 14 に示すよう に boild $\mathrm{P}$ のかわりに sucrose phosphate buffer solution 10cc を加えて培養した対照に比較し， 各反応值とも Corticosteroidの産 生増加が認められた。 (Cortisol equivalent として表現

homogenize した副腎皮質組織 を $100^{\circ} \mathrm{C}$ で 10 分間煮沸，ろ過する ことにより除蛋白，酵素の不活性 化，除去した残りの熱に安定なる 物質の添加培養により Corticosteroid の産生增加をみた。

\section{第 2 項 Dialized $P$ 添加培養} 実験

E1ccに dialized P3cc を添加, 各種の cofactor 存在下に培養し た結果は Fig. 15 に示すように, 対照に比較し，Corticosteroid (Cortisol equivalent) の産生増加 が認められた。 さらに dialized $\mathrm{P}$ の量を変化すると Fig. 16 のよう に dialized $\mathrm{P}$ 量增加とともに Corticosteroid の産生増加が認め られた。この事実は dialysis によ り除蛋白，除酵素した残りの物質 中に Corticosteroid の産生増加を もたらす何らかの物質の存在が想 像される。
Fig. 14. Effect of boild $\mathrm{P}$ on biosynthesis of corticosteroid

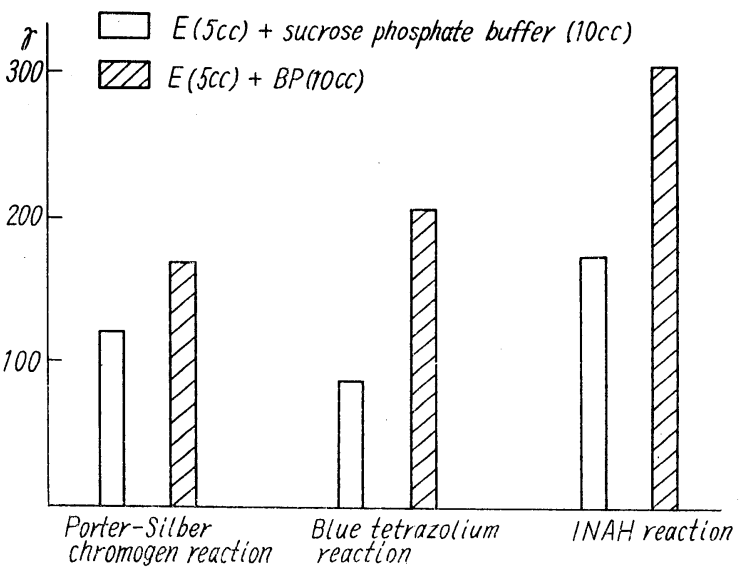

Fig. 15. Effect of dialized $\mathrm{P}$ on biosynthesis of corticosteroid

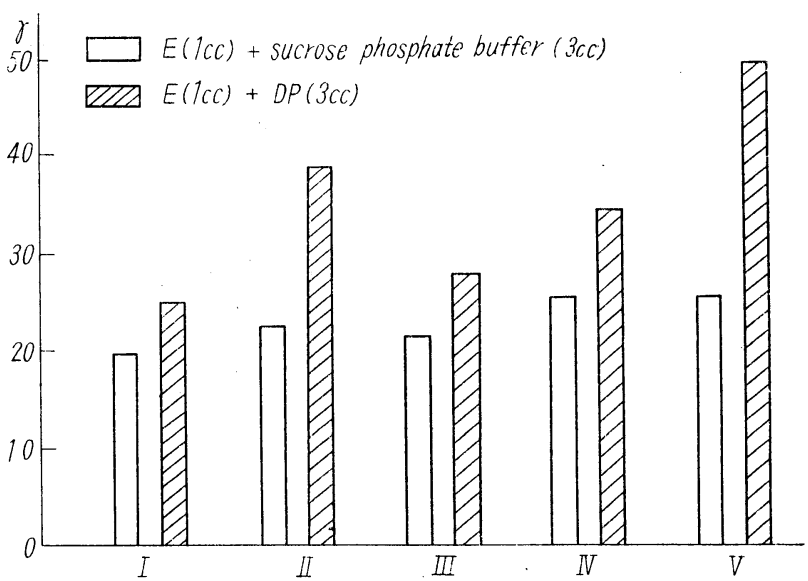

Fig. 16. Effect of dialized $\mathrm{P}$ on biosynthesis of corticosteroid

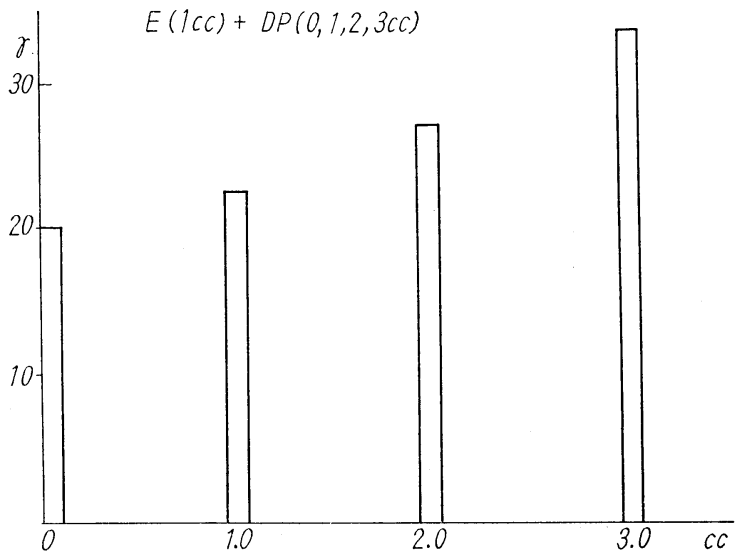

第39巻 第 9 号 


\section{第 3 項 Lyophilized P 添加培養実験}

dialized P 15cc 相当量をさらに lyophilize したものを加えた培養実駚では，Fig. 17 に示すように Corticosteroid 産生増加の効果はさらに大になるのを認めた。乙の実験成績より, この物質が低温にも安定 な物質であることがわかる。

第 4 項 Chloroform unsoluble boild P (CUBP) 添加培養実験

E1cck choloroform unsoluble boild P (2cc) を加えて培養した実験でも, Corticosteroid の産生増加 を認めた。すすなわち, boild P 中の steroideal 物質を chloroform で除去した残りの物質でも, 活性を示 すととが認められた。

Fig. 17. Effect of lyophilized $\mathrm{P}$ on biosynthesis of corticosteroid

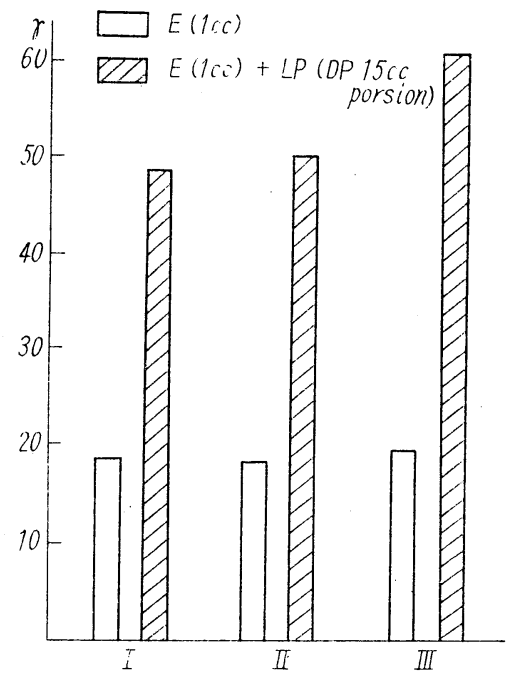

Fig. 18. Effect of chloroform unsoluble boild $\mathrm{P}$ on biosynthesis of corticosteroid

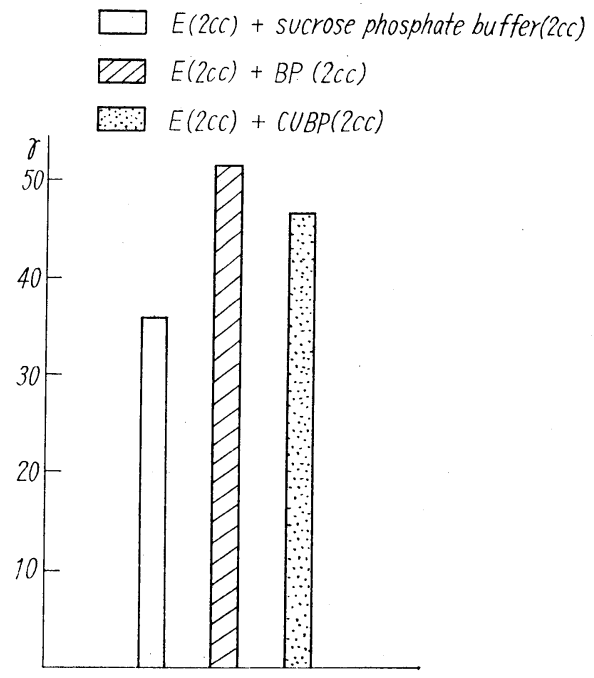

第 6 章 総括，考按ならびに結論

副腎皮質の形態学的，組織学的構造については1886年 Arnold ${ }^{26)}$ が波質を球状層，束状層および網状層の 3 層に区別して以来，今日に至つている。一方，副腎皮質の構造と機能との相関関係については，副腎皮質 の分泌層を球状層のみとする escalater または cell migration theory が提唱されたが，その後，Deane一

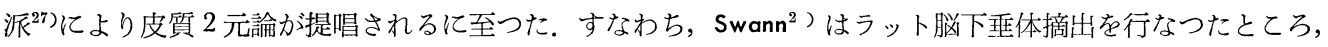
球状層はほとんど変化しないてとをみた。 また Deane ${ }^{27}$ (28) らも同様の所見をラット，大，モルモット等に認 め, ACTH の支配を受けているのは, 束状層で, 糖質 Corticosteroid が分泌され, 球状層は下垂体の支配 を受けない自律的な屏で，鉱質 Corticosteroid を分泌するとした，一方，Ayres は球状層より Aldosterone が，束状層より Cortisol, Corticosterone が分泌されるととは確実であるとしている.

牛副腎皮質組織と各種 Corticosteroid intermediate の添加培養を行なつた本実験では，球状風組織にお いて Corticosterone の産生は認められ，Aldosterone はその spot を涩めるのみで substrate を変えても産 生量に増減はなかつた。また Cortisol の産生は認められなかつた。乙れに反し，束網状層組織ではCorticosterone, Cortisol の産生がともに認められたが， Aldosterone の産生は認められず，したがつて，全層に 3 $\beta$-dehydrogenase, 21-11-hydroxylase の活性が存在するが，18-hydroxylase 活性は球状渞のみに，また， $17 \alpha$-hydroxylase の活性は束網状首のみに存在すると考えられる。とのととより, Aldosterone は球状層よ 
り，Cortisol は束網状層より，また Corticosterone は全層より分泌されるものと考えられる.なお，ての 際 Cholesterol corticosteroidgenic sequenceの各段階においてTPNH が cofactor として必要 ${ }^{(0)}$ (34)で, た

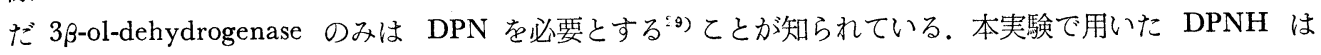
pyridine nucleotide transhydrogenase の作用を受けて TPNH となり利用されたと考えられ，また ATP の效果は Kornberg ${ }^{5}$ ) が認めたように ATP + DPN $\rightarrow$ TPN の反応を介して利用されたと考えられる. 一方, Hechter の Cholesterol corticosteroidgenic sequence そよると, Cholesterol が重要な intermediate と 目されているが，Acetate および Cholesterol の添加培養を行なつた本実験では球および束網状層共に Corticosteroid の著明な産生増加を認めなかつた。 このととについては ACTH の欠如と言うことが関係し ているかも知れず，基質として加えた Cholesterol が， endogenous cholesterol の metabolic pool と十分 はいりえなかつたかも知れないととも考慮する必要がある。しかし，さらに Cholesterol を経ないで Corti-

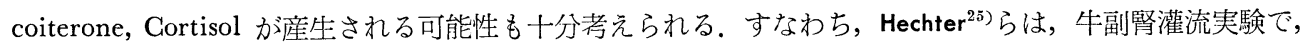
${ }^{14} \mathrm{C}$-acetate を基質として灌流したとてろ, 産生された Cortisol, Corticosterone の specific activityに比較 し，組織中の free Cholesterol, ester Cholesterol や血中 Cholesterol のそれが非常に少ないととを観察し ている. また，Stone \& Hechter ${ }^{36)}$ が ${ }^{14} \mathrm{C}$-Cholesterol を基質として行なつた牛副腎灌流実験では ACTH の投与により，産生された Corticosteroid の specific activity は19倍も増加するのに比較して, Corticosteroid の産生量は 5 倍弱しか増加しないととをみている。また ${ }^{14} \mathrm{C}$-acetate を基質とせる同様の灌流実験で は Corticosteroid の specific activity は1.5倍しか示さなかつたとと等より, Acetate から Corticosteroid への代謝経路に non-cholesterol route のあるととが推定される. また Heard らも Sodium-acetate-1-14 $\left.\mathrm{C}^{8}\right)$ を静脈投与した妊馬尿中に estrogen の specific activity を認めたが, Cholesterol の specific activity は Estrone の1/5にも達しないのをみており，また Cholesterol-4- ${ }^{14} \mathrm{C}$ 投与例 ${ }^{9}$ では，尿中に ${ }^{14} \mathrm{Cを}$ 検出しなかつ たとと， ${ }^{14} \mathrm{C}$-acetate による培養実験6)で中性 Corticosteroid に specific activity ねみたが， ${ }^{14} \mathrm{C}-\mathrm{Ch}$ には転化しないと言う結果を得ている。一方，non-cholesterol route を検討する目的で，副腎皮質中に存在 する intermediate の検討を行なつたとてろ, boiling または dialysis により蛋白を分離した残りの熱に比 較的安定な物質で, lyophilize により変化せず，また chloroform ですでに存在する steroideal 物質を除 去しても Corticosteroid 産生に活性を示す物質が副腎皮質中にすでに存在することが判明した. boiling に 安定で dialysis により容易に透析される物質は酵素でないてとは明らかであるが，てれが基質としてCorticosteroid 産生に関与しているものであるか，あるいは cofactor として関与しているものであるかについて は不明である。十分量の DPNH, ATP の存在下において，本物質を加えることにより Corticosteroid の 生成量が約 2 倍にまで増加したてとは，本物質が cofactor としてより基質として作用したてとを考えさせ られる. chloroform で steroideal 物質を除去しても, なお一部活性を示すととろより考察すれば, ての物 質は基質としてのみでなく， cofactor としても一部関与していると考えた方が妥当であるかも知れない. いずれにしても，乙の物質の分析をすることにより，non-cholesterol route の存在の解明の助けとなるので はないかと考える。

\section{第 2 編 Androgen, Estrogen 産生に関する問題}

\section{第1章 緒言}

Steroid hormone の生合成経路については Fig. 19. 亿示すような経路が現在のとてろ, Dorfman らに より推定されており，乙れらの経路のうち Pregnenolone, Progesterone を通る各経路については徳田 ${ }^{7} ら$ が各種内分泌蔵器の培養実験で, また Cholesterol を経ない何らかの経路の存在の可能能については, 前編 において述べたが，乙れらの各 step があらゆる内分泌蔵器で同じように証明しうるわけでなく，Corticosteroid への経路は副腎で, また Androgen への経路は箤丸および卵巣で, Androgen から Estrogenへの経 
Fig. 19. Biosynthesis sequence of corticosteroid, androgen and estrogen

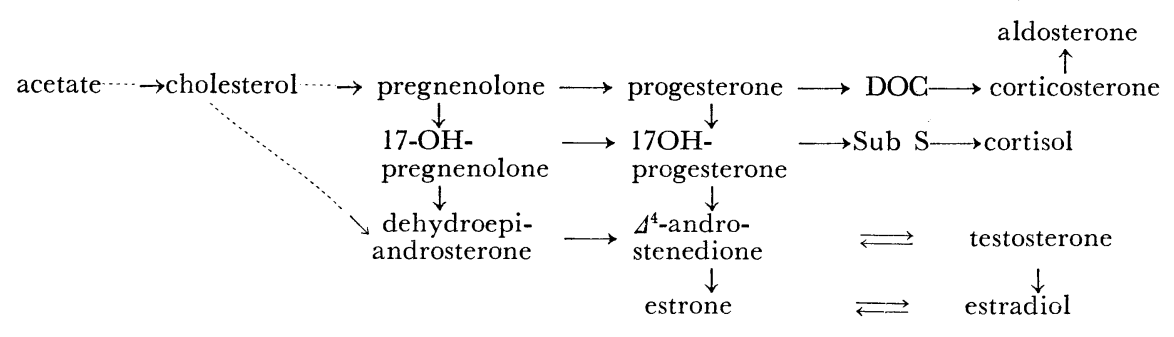

路は胎盤で証明可能である.

副腎の培養実験では Pregnenolone, Progesterone より比較的容易に Corticosterone, Cortisol が産生さ れ，等丸でも同様 $\Delta^{4}$-Androstenedione, Testosterone が産生される。また卵巣では, Pregnenolone, Progesterone から estrogen が得られるに比較して，胎盤では estrogen の産生が非常に困難であることと，副 腎，睪丸，卵巣では Progesterone を経てそれぞれ Corticosteroid，androgen, estrogen が分泌されるにか かわらず, Progesterone が分泌されず, 胎艋の場合にのみ estrogen 生合成の中間代謝産物と考えられる

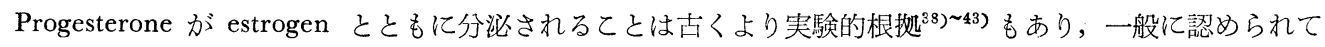
いるが，このととの理由に関する実験成績は現在までのとてろあまりない．とのことに関連して近年胎盤に おける Corticosteroid の産生の可能性が認められる実験成績 ${ }^{38}{ }^{44)}{ }^{49}$ が次々と発表され，DeCourcy, ${ }^{44)}$ Steammler は胎盤における Corticosterone, Cortisol の産生の可能性を主張しているが，Baulier, ${ }^{48)}$ 松葉 ${ }^{49}{ }^{29}$ 17OHCS の産生はないと結論し，胎盤中の $17 \alpha$-hydroxylase の存在を否定している，てのように，胎盤にお ける $17 \alpha$-hydroxylase の存在が胎盤での Progesterone, estrogen の同時分泌に関係するのではないかとの 想定のもとに, 各種内分泌㵴器に Pregnenolone または Progesterone の添加培養実験を行ない興味ある知 見を得た。

\section{第 2 章 牛副留皮質組織と Pregnenolone, Progesterone 添加培養実験}

\section{第 1 節 実験方法}

前編第 4 章において行なつたと同様の実験すなわち, 牛副腎皮質球状首は slice 亿, 束網状首は homogenate にして sodium fumarate $(5 \mathrm{mM})$, nicotin amide $(5 \mathrm{mM})$, ATP $(1 \mathrm{mM})$, DPNH $(0.5 \mathrm{mM})$ を含有した 10cc Krebs-Ringer phosphate buffer solution ( $\mathrm{pH}$. 7.4) 亿上記組織 $5 \mathrm{~g}$ と 0.2cc propylen glycol に溶解 した Pregnenolone または Progesterone を加えて 2 時間振とう培養した.

\section{第 2 節 実験成績}

\section{第 1 項 Pregnenolone 添加培養実験}

球状層組織および束網状層組織に Pregnenolone を加えて培養した粗抽出物をそれぞれ benzene-methanol-water system で paper chromatography を行ない Fig. 20.のような結果を得た。すなわち，球状層 では Corticosterone のRfに一致せる紫外線吸収带を, また束網状凮では大量の $\Delta^{4}$-3-Ketosteroid を得, そ のRf值は, Corticosterone, Cortisol のそれに一致した. この solvent front の部分をさらに ligroinmethanol-water system で展開老行ない，Fig. 21 のような成績を得た. 共に Progesteroneのスポットは ほとんど涩められなかつた。

\section{第 2 項 Progesterone 添加培養実験}

Progesterone を添加培養せる際の benzene-methanol-water system による paper chromatography は Fig. 22. のようで Pregnenolone を添加した時と同様, 束網状層で大量の Corticosterone, Cortisol の産 生が浔められた。

このように副腎皮質束網状風組織では $\mathrm{C}^{17}, \mathrm{C}^{21}, \mathrm{G}^{11}$ 位の hydroxylation が次々に行なわれる成績を得 第39巻 第 9 号 
Fig. 20. Paper chromatograph of corticosteroid produced by pregnenolone incubation $\mathrm{B}_{5}$ system

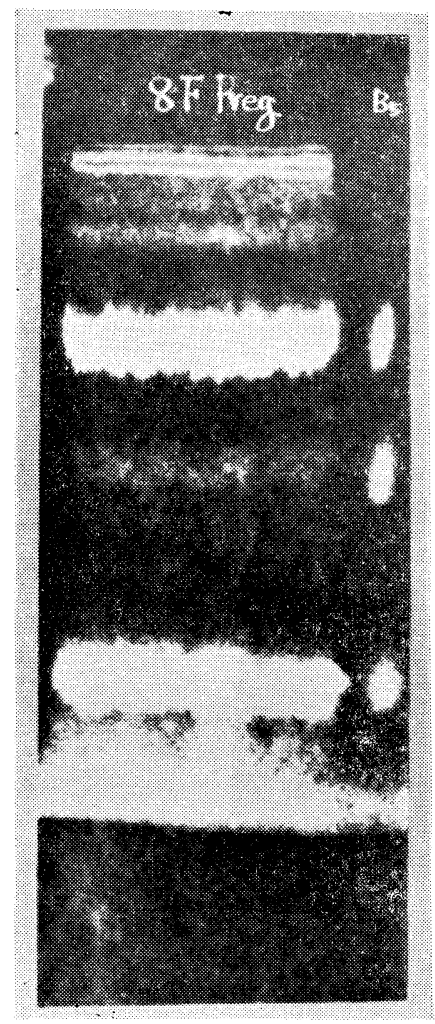

zona fasciculata-reticularis

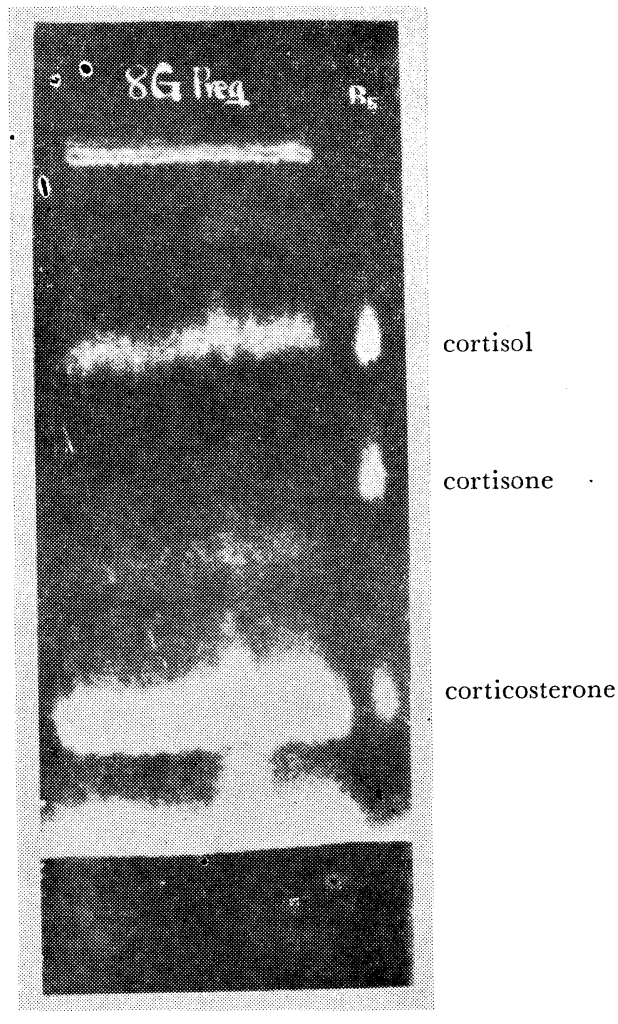

zona glomerulosa

た。したがつて，本実験では副腎における 17 明するものである.

\section{第 3 章 卵巣，童丸および胎盤組織の ${ }^{3} \mathbf{H}$-Progesterone 添加培養実験}

\section{第 1 節 実験方法}

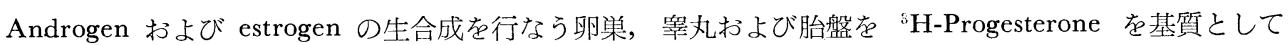
Fig. 23, 24 のような条件で培養および抽出した. なお, incubation medium 中には nicotin amide, Mg $\mathrm{SO}_{4}$, sodium fumarate, ATP, DPNH を加えた。

\section{第 2 節 実験成績}

第 1 項 人卵巣と H-Progesterone 添加培養実験

正常月経周期の子宮筋腫患者で，增殖期に手術した際に得た卵巣 $5 \mathrm{~g}$ slice にし，30cc の incubation medium と共に培養を行なつた。 粗抽出物について ligroin-methanol-water system により展開を行なつ た場合の actigraph は Fig. 25のようで paper chromatography 上, pilot のTestosterone よりやや polar な位置に peak か認められた。 との peak の部分のみを溶出し50rの Testosterone および pyridine-acetic anhydride (1:1) を加え, 室温にて一昼夜放置し, acetylation を行ない, このものについてふたたび, 
ligroin-methanol-water system を用い paper chromatography を行なつたところ Fig. 26 に示すように pilot の 17-hydroxy progesterone に一致して紫外部吸収带を, また acetyl 化された testosterone acetate は solvent front そ紫外部吸収带を認めた。 ての actigraph が Fig. 27 に示すようで, pilotの 17-hydroxy progesterone に一致して peak を認め, testosterone acetate 部には peak が認められなかつた。 ての17hydroxy progesterone 部は Fig. 28 に示すように benzen-ligroin-methanol-water system でも 17-

Fig. 21. Paper chromatograph of corticosteroid produced by pregnenolone incubation $\mathbf{B}_{\mathrm{a}}$ system

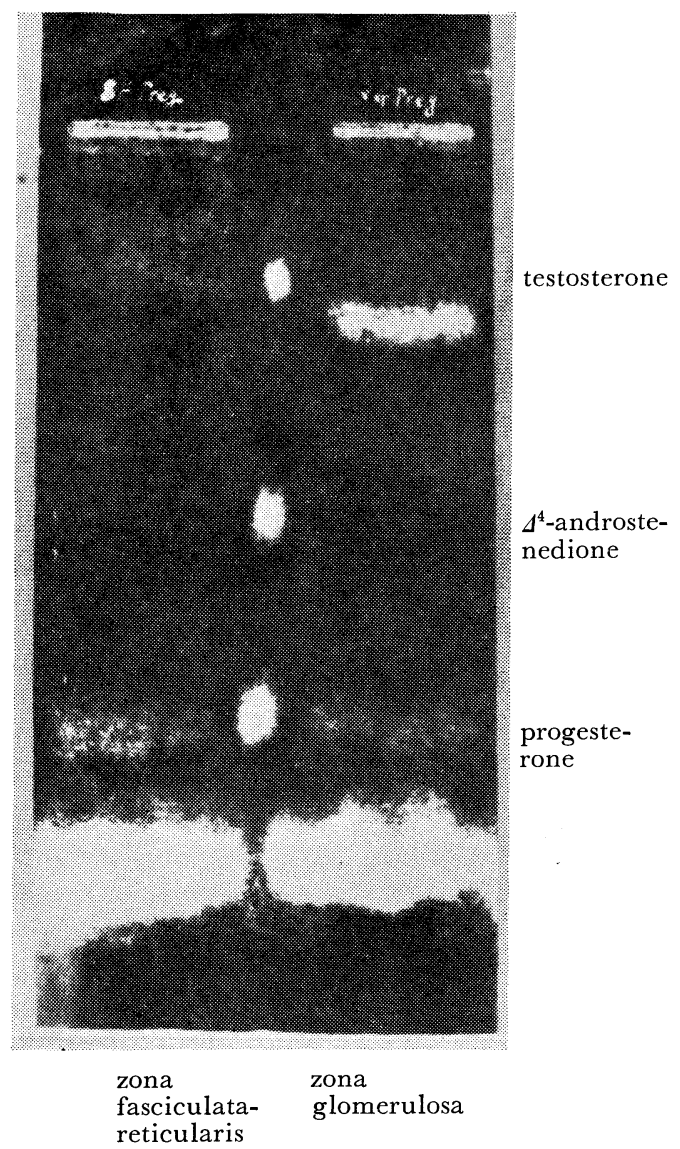

Fig. 22. Paper chromatograph of corticosteroid produced by progesterone incubation $\mathrm{B}_{\tilde{5}}$ system, zona fasciculata-reticularis

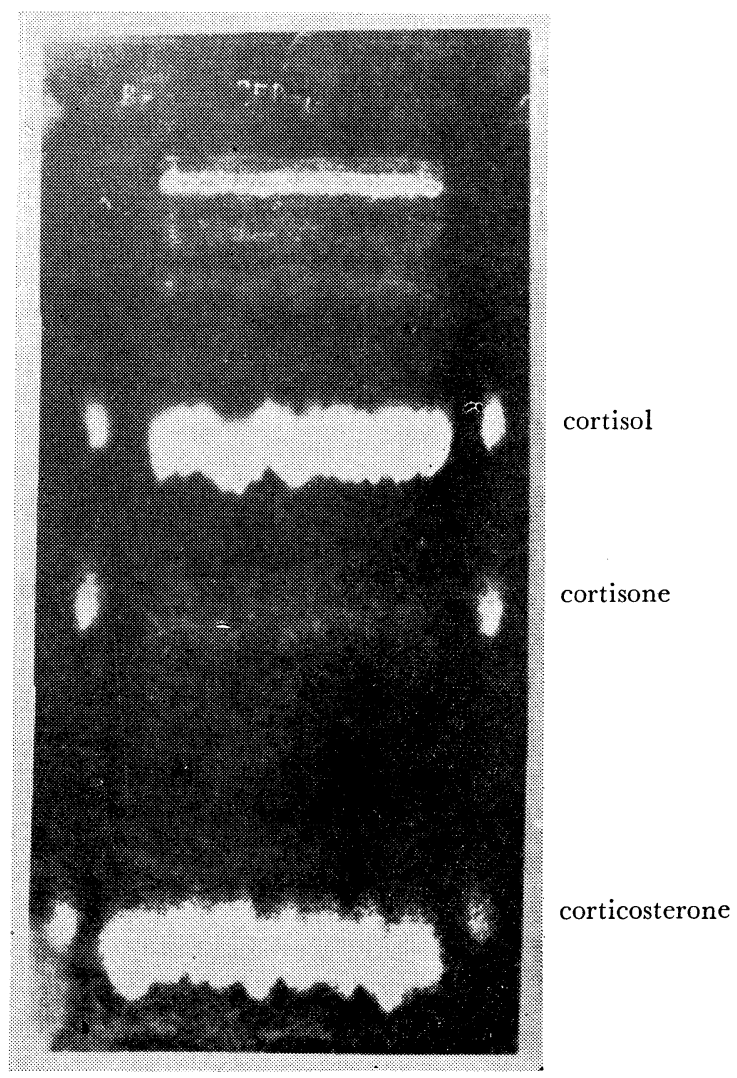

Fig. 23. Method of incubation

human ovary slice $5 \mathrm{~g}$ in $30 \mathrm{cc}$ Krebs-Ringer phosphate buffer solution $\mathrm{pH} 7.4$ rat testis slice $5 \mathrm{~g}$ in $10 \mathrm{cc}$ Krebs-Ringer phosphate buffer solution $\mathrm{pH} 7.4$

human placenta minced tissue $20 \mathrm{~g}$ in $30 \mathrm{cc}$ Krebs-Ringer phosphate buffer solution pH 7.4 or in $0.25 \mathrm{M}$ sucrose phosphate buffer solution $\mathrm{pH} 7.0$

$$
\mid \begin{aligned}
& \leftarrow^{3} \mathrm{H} \text {-progesterone } 7 \times 10^{6} \mathrm{c} / 100 \mathrm{sec} / 10 \mathrm{cc} \text { medium } \\
& 37^{\circ} \mathrm{C} \text { 3hr. incubation } \\
& \text { gas phase air }
\end{aligned}
$$

extracted with acetone 
Fig. 24. Purification of neutral steroid

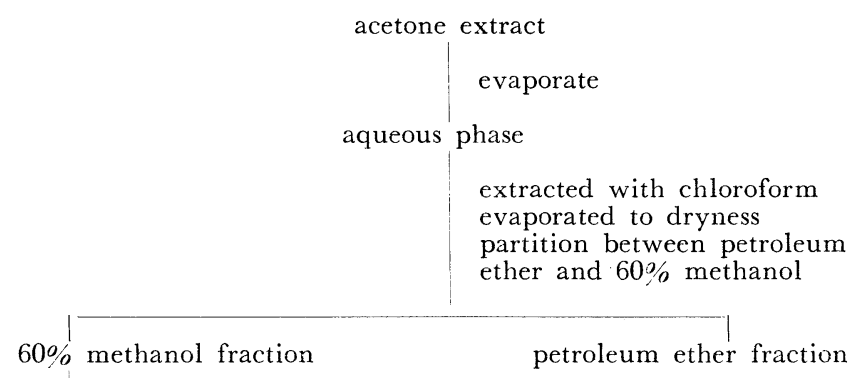

evaporate

aqueous phase

extracted with chloroform evaporated to dryness

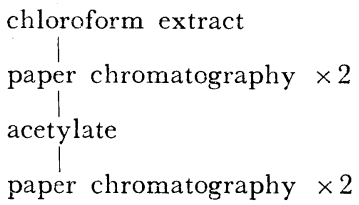

hydroxy progesterone に一致した peak を得た.その sulfuric acid chromogen spectrum は $290 \mathrm{~m} \mu$. $430 \mathrm{~m} \mu$ に吸収の peak を示し，また ultraviolet absorbtion spectrum でも $240 \mathrm{~m} \mu$ に peakを示し standard 17-hydroxy progesterone のそれと完全に一致した. かくて Fig. 25 において Testosterone より極性 の大である部に peak を示した物質が 17-hydroxy progesterone であると同定した.

\section{第 2 項 白鼠䁄丸ट 'H-Progesterone 添加培養実験}

Human chorionic gonadotropin 投与（投与量 1 日300U 7 日間）を受けた Wister 系白鼠睪丸2.5gを slice とし， incubation medium と共に同様の実験を行なつた。粗抽出物について ligroin-methanol-water system で展關した actigraph は Fig. 30.のようで，Testosterone および 17-hydroxy progesterone の部

Fig. 25. Actigraph of corticosteroid produced by ${ }^{5} \mathrm{H}$-progesterone incubation with ovary

$\mathrm{B}_{\mathrm{a}}$ system

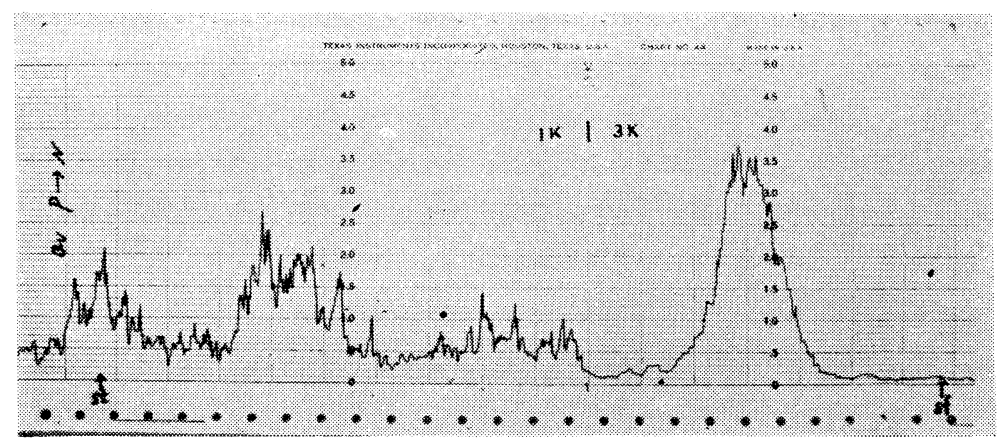


分にpeakが認められた.ての部を pyridineacetic anhydride (1:1) で acetyl 化し, 再び ligroin-methanol-water system で展 開した actigraph は Fig. 31.のようにな り, 17-hydroxy progesterone に一致して peak を認めると共に, Testosterone acetate 部に軽度の peak を認めた。 この17-hydroxy progesterone の産生は ultraviolet absorbtion spectrum および sulfuric acid chromogen spectrum で確認した。

\section{第 3 項 人胎盤と ${ }^{2} H$-Progesterone添加 培養実験}

正常妊娠10ケ月で狭骨盤のために帝王切 開術を行なつた際に得た人胎盤組織 $20 \mathrm{~g}$ を $30 \mathrm{cc} の$ incubation medium と共に培養し た. 胎艋では incubation medium として Krebs-Ringer phosphate buffer solution および $0.25 \mathrm{M}$ sucrose phosphate buffer solution の両者を用いたが，共に Progesterone 部に添加せる ${ }^{3} \mathrm{H}$-Progesterone の peak を認めるのみで，他の部に peak は 認められなかつた. Fig. 32. は sucrose phosphate buffer solution で培養し, ligroin-methonol-water system で展開し た actigraph である. 17-hydroxy progesterone の産生を認めることが分来なかつた。 また天津の方法で抽出した phenolic fraction $の$ ligroin-benzen-methanol-water systeme による展開の actigraph にも何ら
Fig. 26. Paper chromatograph of 17-hydroxy progesterone and testosterone acetate after acetylation by pyridine-acetic anhydride $\mathrm{B}_{\mathrm{a}}$ system

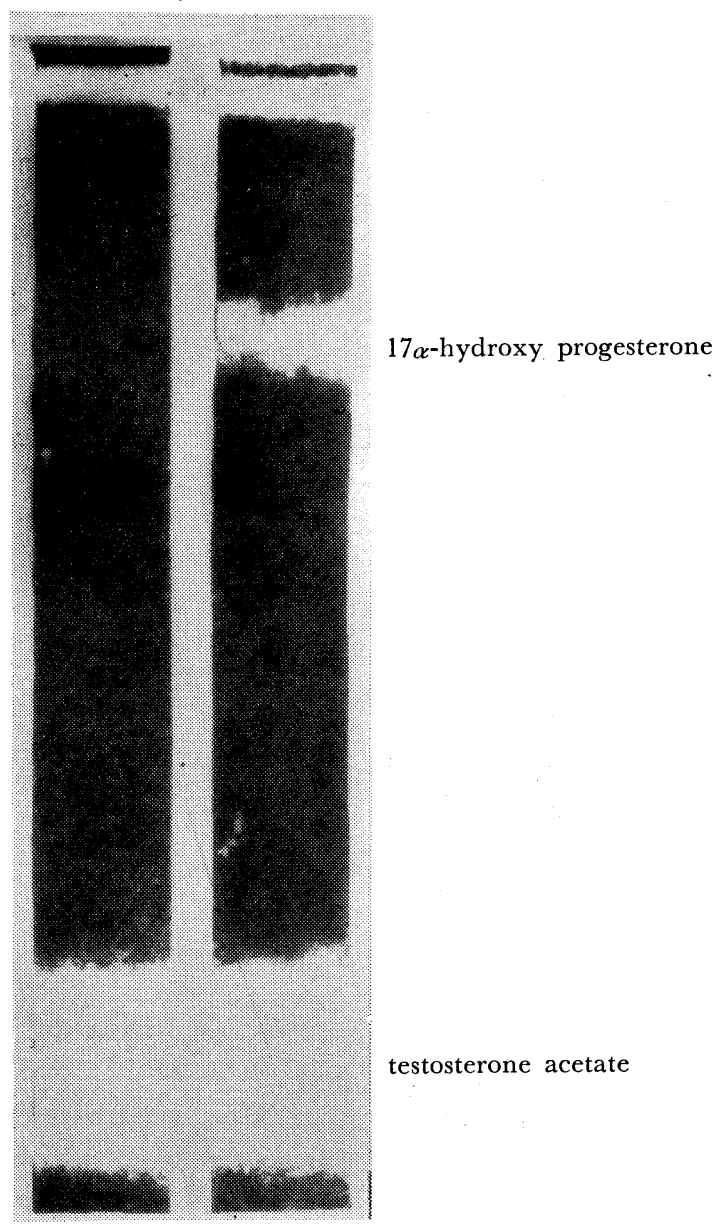

Fig. 27. Actigraph of 17-hydroxy progesterone and testosterone acetate after acetylation by pyridine-acetic anhydride

$\mathrm{B}_{\mathrm{a}}$ system

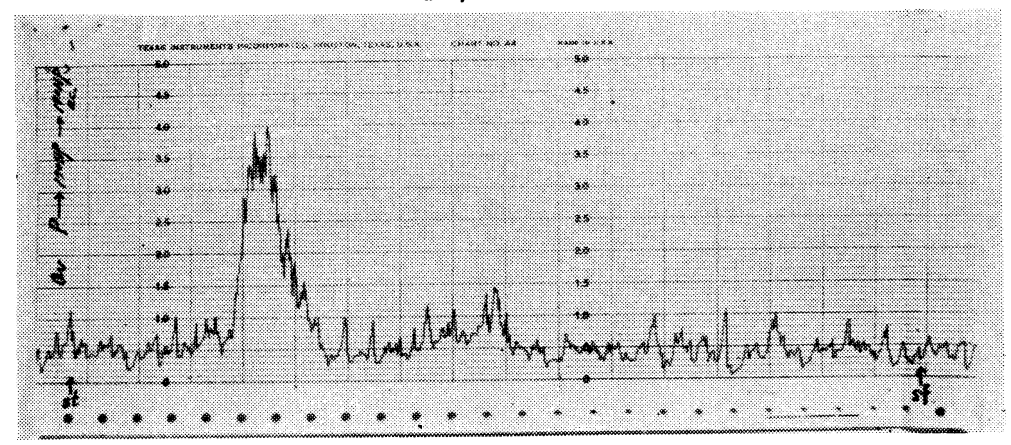


Fig. 28. Actigraph of 17-hydroxy progesterone and testosterone acetate after actylation by pyridine-acetic anhydride

$\mathrm{B}_{3}$ system

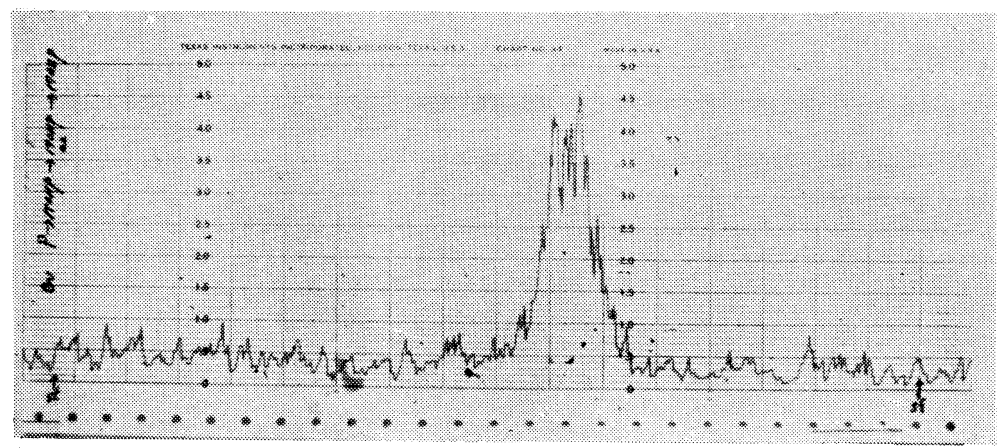

Fig. 29. Sulfuric acid chromogen spectrum and ultraviolet absorption spectrum of 17-hydroxyprogesterone produced by ${ }^{2} \mathrm{H}$-progesterone incubation with human ovary

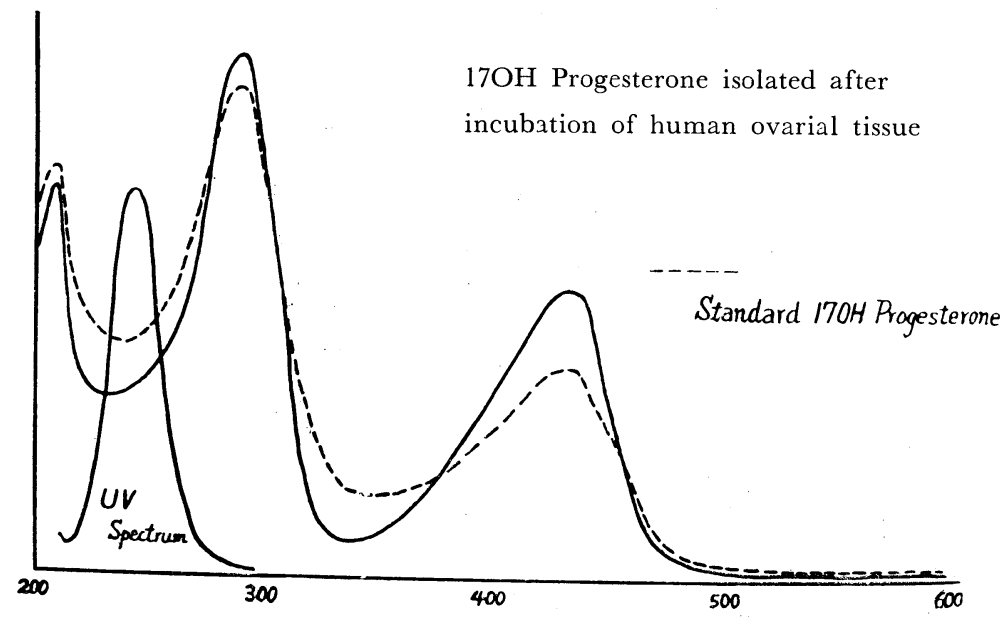

Fig. 30. Actigraph of corticosteroid produced by ' $H$-progesterone incubation with rat testis

B $_{\mathrm{a}}$ system

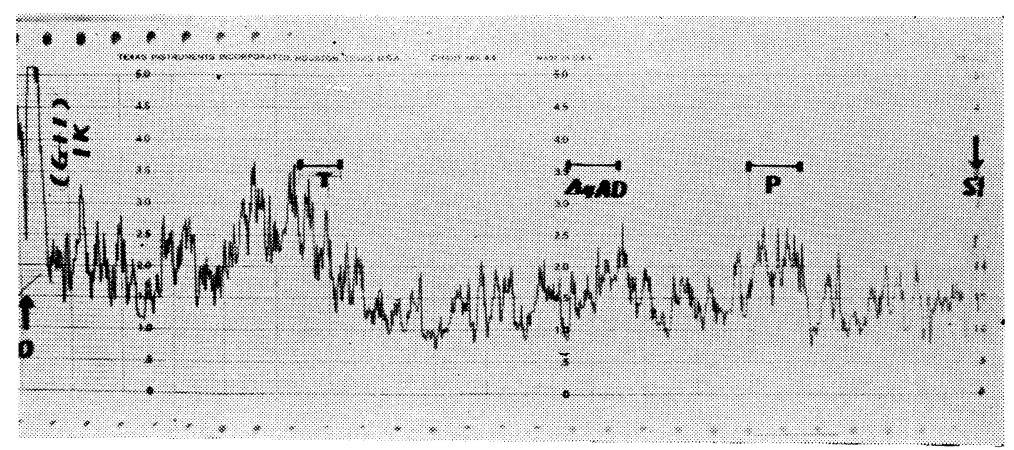

第39巻 第 9 号 
Fig. 31. Actigraph of 17-hydroxy progesterone and testosterone acetate after acetylation by pyridine-acetic anhydride.

$\mathrm{B}_{\mathrm{a}}$ system

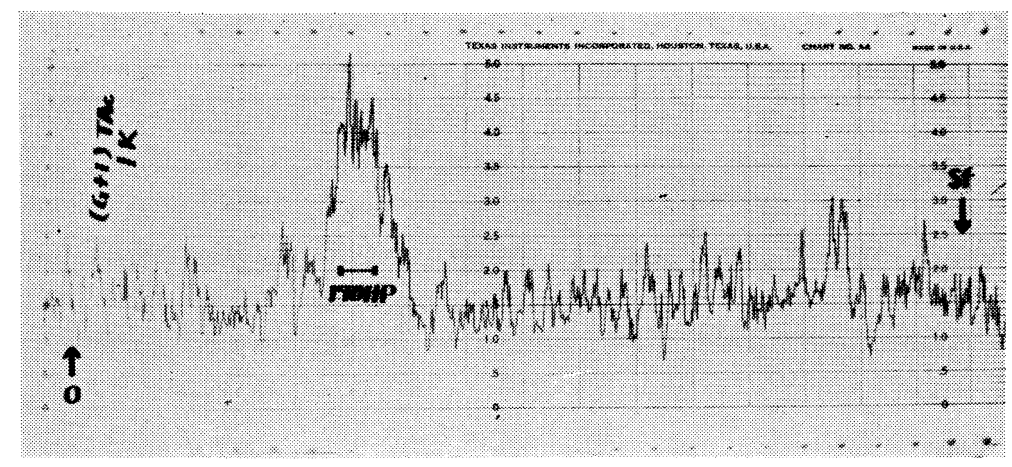

Fig. 32. Actigraph of corticosterord produced by ${ }^{3} \mathrm{H}$-progesterone incubation with human placenta.

$\mathrm{B}_{\mathrm{a}}$ system

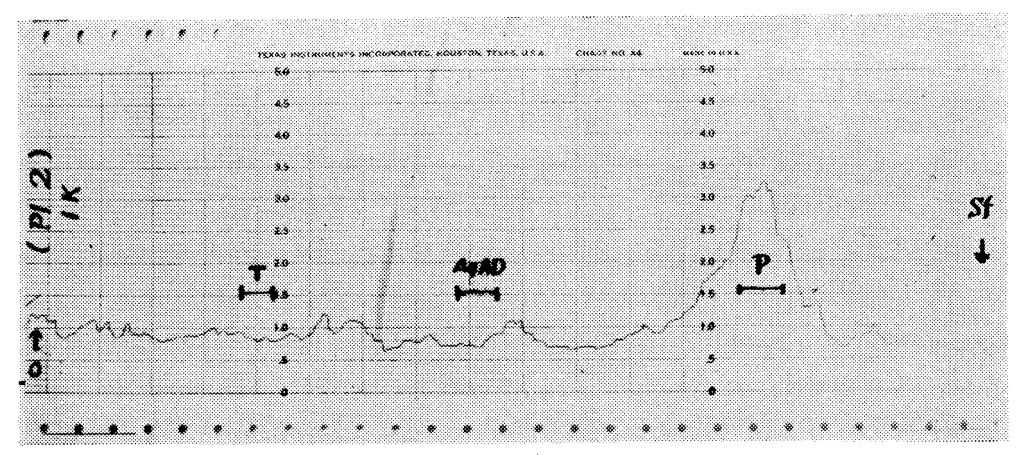

の peak も認めなかつた.

以上のようにして，卵巣および睪丸では，17 -hydroxylase の存在を明らかに証明し得たに反し，胎盤中， には $17 \alpha$-hydroxylase の存在する所見は得られなかつた.

\section{第 4 章 総括，考按ならびに結論}

卵巣から estrogen が分泌されることは以前より明白な事実と考えられているが，その生合成に関しては Testosterone および他の androgen を人に投与した場合, estrogen 様作用のある物質が排泄 ${ }^{50) ~ 55) さ れ ， そ ~}$ れが Estrone, Estradiol, Estriol である ${ }^{56}$ ととがわかり,19-carbon steroid から phemolic estrogen に変換 される可能性が示された.

Baggett \& Engel ${ }^{57}$ ) は人卵巣と Testosterone-3- ${ }^{14} \mathrm{C}$ の培養実験で ${ }^{14} \mathrm{C}-e s t r a d i o l-17 \beta$ の産生を認め，てれを 実証した。

一方，睪丸における androgen の生合成に関しては radioactive な Progesterone と睪丸組織との培養実 験により, Lynn, ${ }^{58) 59)}$ Slaunwhite \& Samuels ${ }^{60)}$ は白鼠，牛，豚などの冝丸で progesterone $\rightarrow 17$-hydroxy progesterone $\rightarrow$ androstenedione $\rightleftarrows$ testosterone の生合成経路を認め, androgen 生合成の主経路であると主 張しており，また Viscelli ${ }^{6}$ ) ら，Savard $\left.{ }^{62}\right)$ らも人卵巣において同様の生合成経路を認めている. 
成人の㐿丸中には少量の Estrone および Estradiol が Goldzieher $\left.{ }^{63}\right)$ らにより認められ, Zondek ${ }^{64) 65)}$ によ り Stallion 殬丸組織中には相当量の estrogenic activity の存在するのを認め Beall ${ }^{66)}$ は Estrone, Estradiol を分離した. Nyman ${ }^{67}$ ) らは sodium acetate-1-14G の Stallion の灌流実験で，箤丸組織および血清中に radioactive Estrone および Estradiol を検出し，睪丸組織でも estrogen が産生されることを認めた。

Solomon $^{68)}$ らは牛卵巣で androgen の前駆物質である Progesterone より $17 \alpha$-hydroxyprogesterone, $\Delta^{4}$-androstenedione への転換を認め, 卵巣においても Cholesterol $\rightarrow$ progesterone $\rightarrow 17 \alpha$-hydroxy progesterone $\rightarrow$ androstenedione (testosterone) $\rightarrow$ estradiol の生合成経路の存在を考えた. Kase ${ }^{69}$ ) らは人卵单homogenate と 7- ${ }^{3} \mathrm{H}$-progesterone および ${ }^{14} \mathrm{C}$ - $17 \alpha$-hydroxy progesterone との培養実験で, Testosterone, Androstenedione を分離し, Warren ${ }^{70)} ら も$, 人卵栄と Progesterone-4- ${ }^{14} \mathrm{G}$ との培養実験で, estrogen の中間 代謝産物と考えられる 17 $\alpha$-hydroxy progesterone, Androstenedione を分離した. これに反し Lanthier and Sandor は Pregnenolone との培養実験で, Progesterone, $17 \alpha$-hydroxy progesterone の産生を証明し

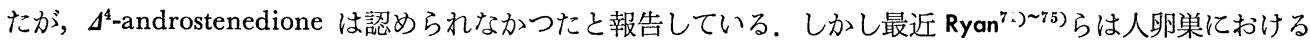
estrogen 生合成の系統的研究を行ない，乙の経路の存在する可能性を十分実証しうるような data を発表し ている。また Short ${ }^{76)}$ は卵胞液および黄体組織よりの Steroid の抽出実験より卵巣の Steroid 生合成に関 して “two cell type”説を唱えている.

胎盤においては progesterone および estrogen が同時に分泌されているととは明白なてとである. Progesterone の生合成については Samuels ${ }^{77)}$ らは白鼠胎盤で Nissum \& Robson ${ }^{78)}$ は牛胎盤で Pregnenolone と 共に培養し，主要産物として Progeseterone を得て $\Delta^{5}$-Pregnenolone $\rightarrow$ Progesterone なる経路を確認した。 人胎盤では Pearlman ${ }^{79}$ らにより同様の経路が確認された。一方 estrogen の生合成に関しては Heard \& O’Donnel/ ${ }^{80)}$ により radioactive Cholesterol を妊馬に投与したとてろ尿中に radioactive Estrone が排泄さ れるという報告があり，その後, in vitro でも Meyer, ${ }^{81)}$ Longchampt $^{82)}$ らは人胎盤で androgen から phenolic estrogen への aromatization が起てるととを認め, Ryan ${ }^{83)}$ らも猿胎盤で, 同様の成績を得ており， 胎船においても卵巣, 殬丸におけると同様の cholesterol $\rightarrow$ pregnenolone $\rightarrow$ progesterone $\rightarrow \Delta^{4}$-androstenedione $\rightarrow$ estrone なる生合成経路の存在が想像されるが，一方人胎盤の培養実験で Ryan ${ }^{84)}$ は $\Delta^{4}$-androstenedione, Testosterone, Dehydroepiandrosteroneのような androgenic steroid から Estrone への変換を認め たが Progesterone, 17 $\alpha$-hydroxy progesterone および adrenal steroid (pregnenolone, 17 $\alpha$-hydroxy prognenolone, cortisol 等) から estrogen への変換は認めるてとが出来なかつたと報告している. また, 胎盤 における Corticosteroid 産生の可能性に関する研究においては古くは妊娠中における glucocorticosteroid の尿中排泄の著明な増加は副腎皮質機能の元進と共に, 胎児副腎および胎盤における Corticosteroid 産生に 由来すると Venning ${ }^{85)}$ は報告したが，彼女 ${ }^{86)}$ は胎盤抽出物に副整皮質作用を liver glycogen deposition

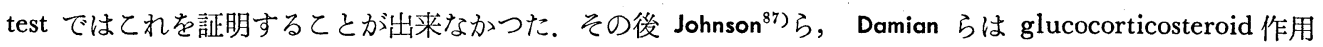
のあるととを証明した. また DeCourcy $\left.{ }^{44}\right)$ ，Stämmler も胎盤抽出物に cortisol. cortisone と同一の Rf 值 を有する steroid を分離し，胎盤における Corticosteroid 産生の可能性を主張した. また Little \& Rossi ${ }^{88)}$ は人胎盤での培養実験で Porter-Silber chromogen 反応物質としての 17-hydroxy corticosteroid の生合成 を, そしてその後, Little \& Shaw ${ }^{89)}$ は Progesterone-4- ${ }^{14} \mathrm{G}$ との培養実験で 17-hydroxy progesterone の産生 を人胎盤の soluble fraction に認めた. これに対し Baulier $\left.{ }^{48}\right)$ らは Addison 氏病患者の妊娠例についての 研究結果では，胎盤における 17-hydroxy corticosteroid の産生を認めなかつた，Cohen年）らは Cushing's syndrom のため, 副腎摘除を行なつた妊娠婦人の尿中 Cortisol, Cortisone, Tetrahydrocortisol, Tetrahydrocortisone を測定した結果, 胎盤, 胎児副腎より 17-hydroxy corticosteroid の産生か認められるような結果 を得ることは出来なかつた． 松葉 ${ }^{49}$ も犬妊娠子宮での Progesterone 灌流実験および胎盤䄉毛と Progesterone の培養では 17-hydroxy corticosteroid の増加が認められなかつたと報告し，てれらとDeCourcy らの 間には胎盤における $17 \alpha$-hydroxylase の存否をめぐつて完全に相入れない逆の結果である.

私が行なつた ${ }^{3} \mathrm{H}$-Progesterone と人胎盤組織との培養実験では 17-hydroxy progesterone および pheno- 
lic estrogen の産生を証明し得なかつた。ただ，ての際用いたかかる actigraph 法で明らかな peak を得る ためには相当量の radioactivity を必要とするために胎盤における $17 \alpha$-hydroxylase の存在を早急に否定 するととは出来ないが，ての酵素の存在が他の臓器に比してはるかに少ないととは明らかである，胎盤には $17 \boldsymbol{\alpha}$-hydroxylase がなく，睪丸や卵巣で行なわれる estrogen 生合成経路が，胎盤では存在しないのではな いかと言う可能性の証拠を提供するものである．副腎皮質では Cholesterol corticosteroidgenic sequence そおいて Pregnenolone, Progesterone は Corticosteroid 産生への中間産物であり, 終末産物ではなく血中 への分泌は起てらない，胎船でも同様に Progesterone が estrogen 産生への中間産物であるならば，血中 への分泌がないのが当然である.とてろが胎艋では Progesterone および estrogen が分泌されており，共 に終末産物であると考えられる。とのととと $17 \alpha$-hydroxylase の存在の可能性が少ないであろうととと考 え合せれば，胎艋における estrogen の産生は Burstein \& Dorfman'.) が adrenal adenoma の virilized woman で想像したように Pregnenolone, Progesterone を経ずして Cholesterol より直接 19-carbon steroid すなわち Dehydroepiandrosterone を経て産生されるか Acetate または他の物質より産生される新しい経路 が存在するのではないかと考光られる。

稿学終るに当たり, 終始御懇篤なる御指導と御校閲の労を睗わつた恩師, 徳田源市教授に深謝するととも に, 貴重な御助言, 御䩒撻を睗わつた教室諸学兄, ことに岡田弘二博士に深く感謝する. な扔, 本論文の要 旨は第34回，第35回日本内分泌学会総会，第10回日本内分泌学会西日本地方会に打いて発表した。

\section{参 考 文 献}

1) STEIGER, M. and T. REICHSTEIN : Nature, $139: 925$, (1937). $269: 122,(1952)$.

3) TAIT, J.F. et al : Nature, $169: 795,(1952)$.

2) TAIT, J.F. et al : Lancet, al : Experientia, $10: 132$, (1954).

5) HECHTER, O. and G. PINGUS : Physiol. Review., 34 : 459, (1954). 6) HAYANO, M. et al : Recent Progress in Hormone Research, $12: 79$, (1956). 7) HAYANO, et al : Rec. Prog. Horm. Res., $12: 118,(1956)$ 8) HEARD, R.D.H. et al : Rec. Prog. Horm. Res., $9: 383$, (1954). 9) HEARD. R.D.H. \& V.J. O'DONNELL : Endocrinol., 54 : 209, (1954). 10) 徳田源市, 岡田弘二: 日本臨床, $20: 2364$, (1962). 11) DEANE, H. W. \& R.O. GREEP : Endocrinol., $40: 417$, (1947). 12) BUSH, J.E. : Biochem. J., $50: 370$, (1952). 13) ZAFFARONI, A. : Rec. Prog. Horm. Res., $8: 51$, (1953). FARONI and E.H. KEUTMANN : J. Biol. Chem., $188: 763$, (1951).

14) BURTON, R.B., A. ZAF15) PORTER G.C. \& R. H. SILBER : J. Biol. Chem., 185 : 201, (1950).

16) NOWACZYNSKI, W.J. et al : Can. J. Biochem. Physiol., $35: 425$, (1957).

17) WEIGHSELBAUM, J.E. \& H.W. MARGRAF : J. Clin. Endocrinol. and Metab., $17: 959,(1957)$. 18) SOMMERVILLE, I.F. : J. Clin. Endocrinol. and Metab., $17: 317$, (1957). 19) ZIMMERMANN, W. : Z. Physiol. Chemie., $233: 257$, (1935). 20) VESTLING, G.S. \& G.F. LATA : Science, $113: 582$, (1951). 21) SWANN, H.G. : Physiol. Rev., $20: 493$, (1940). 22) O’DONNELL, W.M., S. FAJANS \& J.G. WEINBAUM : A.M.A. Arch. Int. Med., $88: 28,(1951)$.

23) HEGHTER, O.: Cholesterol, 309 : Academic Press, (1958). 24) 赤須文男 : 第 7 回日本産科婦人科学会総会, 宿題報告, (1955).

25) HECHTER, O., M.M. SOLOMON, A. ZAFFARONI \& G. PINGUS : Arch. Biochem. Biophys., 46 : 201, (1953). 26) ARNOLD, J. : Virchows Arch., 35 : 64, (1866). 27) GREEP, R.O. \& H.W. DEANE : Endocrinol., $40: 417,(1947)$. 28) DEANE, H.W. \& R.O. GREEP : Am. J. Anat., $79: 117$, (1946). SAMUELS, L.T. et al : Science, $113: 490,(1951)$. 30) RYAN, K.J. \& L.L. ENGEL. : J. Am. Chem. Soc., $78: 2654,(1956)$. 31) SWEAT, M.L. \& M.D. LIPSCOMB : J. Am. Chem. Soc., $77: 5185,(1955)$. 32) SWEAT, M.L. : Fed. Proc., $15: 369$, (1956). 33) GRANT, J.K. \& 第39巻 第 9 号 
K. MONGKOLKUL : Biochem. J., 69 ; 36p, (1958). (1956). 35) KARNBERG, A. : J. Biol. Chem., $182: 805$, (1950).
34) GRANT, J.K. : Biochem. J., 64 : 559, Arch. Biochem. Biophys., $51: 457,(1954)$.

37) 徳田源市：第34回日本内分泌学会総会発表, (1961)。 38) SALHANICK, H.A. et al : J. Clin. Endocrinol. and Metab., $16: 1120$, (1956). J. : Klin. Wshr., $33: 697,(1955)$. 40) ZANDER, J. : Nature, $174: 406,(1954)$. 39) ZANDER, 昌男：日産婦誌, $5: 1243,(1953)$. 42) BROWNE et al : Am. J. Obst., $38: 927,(1939)$. 41) 前山 石塚直隆：日産婦誌，9:907, (1957). 44) DECOURGY, G. et al : Nature, $170: 494,(1952)$. 45) JOHNSON, R.H. \& W.J. HAINES : Science, 116 : 456, (1952)。46) 鈴木基一：日産婦誌, 10 : 1679, (1958)。47）滝川秀夫：日産婦誌, $10: 1659$, (1958). 48) BAULIER, E.E. et al : J. Clin. Endocrinol. and Metab., $16: 690,(1956)$. 49) 松葉三千夫 : 最新医学，12:1170, (1957). 50) STEINACH, E. \& H. KUN : Lancet, $2: 845$, (1937). 51) GALLOW, N.H., R.K. CALLOW \& C.W. EMMENS : J. Endocrinol., $1: 99,(1939)$. 52) DORFMAN, R.I. \&J.B. HAMILTON : Endocrinol., $25: 33$, (1939). 53) HOSKINS, W.H., J.R. COFFMAN, F.G. KOGH \& A.T. KEUYON : Endocrinol., 24 : 702, (1939). 54) NATHANSON, I.T. \& L.E. TOWNE : Endocrinol., $25:$ 754, (1939). 55) FOSS, G.L. : Lancet, $1: 502$, (1939). 56) NATHANSON, I.T. et al : J. Clin. Endocrinol. and Metab., $12: 1172$, (1952). 57) BAGGETT, B. \& L.L. ENGEL : J. Biol. Chem., 221 : 931, (1956). 58) LYNN, W.S. Jr. : Fed. Proc., $15: 305$, (1956). 59) LYNN, W.S. Jr. \& R.H. BROWN : J. Biol. Chem., 232 : 1015, (1958). 60) SLAUNWHITE, W.R. Jr. \& L.T. SAMUELS : J. Biol. Chem., $220: 341$, (1956). 61) VISGELLI, T.A., M.E. LOMBARDO \& P.B. HUDSON : Fed. Proc., 16 : 335, (1957). 62) SAVARD, K. et al : J. Clin. Endocrinol. and Metab, $16: 1629$, (1956). 63) GOLDZIEHER, J.W. \& I.S. ROBERTS : J. Clin. Endocrinol. and Metab., $12: 143,(1952)$. ZONDEK, B. : Nature, $133: 494,(1934)$. 67) NYMAN, M.A., J. GEIGER \& J.W. GOLDZIEHER : J. Biol. Chem., $234: 16$, (1959). 68) SOLOMON, S., R.V. WIELE \& S. LIEBERMAN : J. Am. Chem. Soc., $78: 5453$, (1956). 69) KASE, N., E. FORGHIELLI \& R.I. DORFMAN : Acta Endocrinol., 37 : 19, (1961). 70) WARREN, J.C. \& H.A. SALHANANICK : J. Glin. Endocrinol. and Metab., $21: 1218$, (1961). RYAN, K.J. \& O.W. SMITH : J. Biol. Chem., $236: 705,(1961)$. 72) RYAN, K.J. \& O.W. SMITH : J. Biol. Chem., 236 : 710, (1961). 73) RYAN, K.J. \&O.W. SMITH : J. Biol. Chem., 236 : 2204, (1961). 74) RYAN, K.J. \& O.W. SMITH : J. Biol. Chem., $236: 2207,(1961)$. SMITH, O.W. \& K.J. RYAN : Endocrinol., 69 : 970, (1961). 76) SHORT, R.U. : J. Endocrinol., $24: 59,(1962) . \quad 77)$ SAMUELS, L.T. et al : Science, $113: 490,(1950) . \quad 78)$ NISSUM, J.A. \& J.M. ROBSON : J. Endocrinol., $8: 329,(1952)$. 79) PEARLMAN, W.H., E. GERGES \& M. THOMAS : J. Biol. Chem., $208: 231$, (1954). 80) HEARD, R.D.H. \& V.I. O'DONNELL : Endocrinol., 54 : 209, (1954). 81) MEYER, A.S. : Biochem. et Biophys. Acta., $17: 44,(11955)$. 82) LONGGHAMPT, J.E. et al : Endocrinol., $66: 416,(1960)$. 83) RYAN, K.J., K. BENISSCHEKE \& O.W. SMITH : Endocrinol., 69 : 613, (1961). 84) RYAN, K.J. : J. Biol. Chem., $234: 268$, (1959). 85) VENNING, E.H. : Endocrinol.,39 : 203, (1946). 86) VENNING, E.H. et al : Endocrinol., $45: 430,(1949)$ 87) JOHNSON, R.H. \& W.J. HAINES : Science, $116: 456,(1952) . \quad 88)$ LITTLE, B. \& E. ROSSI : Endocrinol., $61: 109,(1957)$.

89) LITTLE, B. \& A. SHAW : Acta Endocrinol., $36: 455$, (1961). 90) COHEN, M. et al : J. Clin. Endocrinol. and Metab., $18: 1076$, (1958). 91) BURSTEIN, S. \& R.I. DORFMAN : Acta Endocrinol., $40: 188$, (1962). 